\title{
Preprint
}

Post-occupancy evaluation: State-of-the-art analysis and state-of-the-practice review

Peixian Li, Thomas M. Froese, Gail Brager

PII:

S0360-1323(18)30095-7

DOI:

10.1016/j.buildenv.2018.02.024

Reference: $\quad$ BAE 5308

To appear in: Building and Environment

Received Date: 7 December 2017

Revised Date: 15 February 2018

Accepted Date: 17 February 2018

Please cite this article as: Li P, Froese TM, Brager G, Post-occupancy evaluation: State-of-the- art analysis and state-of-the-practice review, Building and Environment (2018), doi: 10.1016/ j.buildenv.2018.02.024.

This is a PDF file of a preprint of an unedited manuscript submitted to Building and Environment. A revised version of this manuscript has been accepted for publication.

Accepted Manuscript available at:

https://onlineacademiccommunity.uvic.ca/froese/publications/ 


\section{Post-Occupancy Evaluation: State-of-the-Art Analysis and State-of-the-Practice Review}

Peixian $\mathrm{Li}^{\mathrm{a},{ }^{*}}$, Thomas M. Froese ${ }^{\mathrm{b},{ }^{*}}$, Gail Brager ${ }^{\mathrm{c}}$

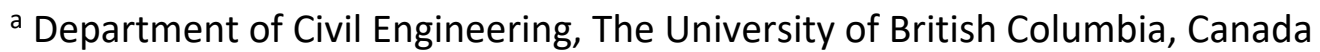

${ }^{\mathrm{b}}$ Department of Civil Engineering, University of Victoria, Canada

${ }^{\mathrm{c}}$ Center for the Built Environment, University of California, Berkeley, USA

*Corresponding Author:

Thomas M. Froese

Email: froese@uvic.ca;

Tel: (1) 250-721-7066

Fax: (1) 250-721-6051

Mail: University of Victoria,

Department of Civil Engineering,

Engineering and Computer Science (ECS) 304,

PO Box 1700 STN CSC, Victoria BC V8W 2Y2, Canada

Courier: University of Victoria,

Department of Civil Engineering,

Engineering and Computer Science (ECS) 304,

3800 Finnerty Road,

Victoria BC V8P 5C2, Canada

\section{Abstract:}

Post-occupancy evaluation (POE) is a process of evaluating the performance of a building after it has been occupied for at least several years. The authors conducted a comprehensive and critical review to provide a both qualitative and quantitative introduction of $\mathrm{POE}$, including a brief introduction of the history, definition and benefits of POE, a statistical analysis of 146 POE projects since 2010, a comparison of 13 existing POE protocols, a summary of emerging research focuses, and potential future research areas. The 146 POE projects were analyzed in terms of building types, countries, purposes, methods used, and key findings. The review of 13 POE 
protocols show the state-of-the-practice POE techniques. Apart from POE projects, the authors present emerging research topics related to the visualization of POE results, analyses of occupant survey database, and measurement of occupancy. Finally, the discussion summarizes the current condition of POE research and proposes five transitions that POE efforts should pursue: from one-off to continuing, from high-level to detailed, from researchers-oriented to owners/occupants-oriented, from academia to industry, and from independent to integrated. This paper provides a thorough introduction of POE to the beginners in this area, as well as informing more seasoned investigators about the trends, gaps, and potential future directions in POE research.

\section{Key words}

Post-occupancy evaluation, building performance evaluation, literature analysis

\section{Acronyms}

BPE (building performance evaluation), CBE (Center for the Built Environment at UC Berkeley), BUS (Building Use Studies), $\mathrm{CO}$ (carbon monoxide), $\mathrm{CO}_{2}$ (carbon dioxide), GB (green building), GIS (geographic information system), GPS (global positioning system), IAQ (indoor air quality), IEQ (indoor environmental quality), PM (particulate matters), POE (post-occupancy evaluation), RH (relative humidity), T (temperature), TVOC (total volatile organic compounds)

\section{Funding Source Declaration}

The first author gratefully acknowledges the financial support from China Scholarship Council and the University of British Columbia. 


\section{Introduction}

Energy consumed in the building sector accounts for $20.1 \%$ of the total delivered energy consumed worldwide and is expected to increase by an average of $1.5 \%$ per year from 2012 to 2040 [1]. This impact is much higher in the U.S., where the building sector is estimated to account for approximately $40 \%$ of total U.S. energy consumption [2]. Meanwhile, the building sector offers great potential for reducing greenhouse gas emissions. Since the 1990s, policies and international standards have been developed to encourage green building (GB) design and construction. In a review of GB research, Zuo and Zhao identified three overarching themes: coverage and definition of $G B$, quantification of cost and benefits of $G B$, and approaches to achieve GB [3].

\subsection{Green Building Certification Systems}

To address the first theme, "What is a green building?", a variety of GB assessment certification systems have been developed. Worldwide, there are roughly 150 tools and methodologies for building assessment and benchmarking [4]. A large portion of them are green building certification systems, i.e., BREEAM (UK), CASBEE (Japan), DGNB (Germany), Green Building Index (Malaysia), Green Building Labelling (China), Green Globes (Canada), Green Mark (Singapore), Green Star (Australia), HQE (France), LEED (US), Living Building Challenge (US), Passive House (Germany), Pearl Rating System (Abu Dhabi), SBTool (international), WELL Building Standard (US), etc. While the place of origin of these certification systems is indicated in parenthesis above and shown in Figure 1, the uptake of some is more widespread. These certification systems are primarily used in the design phase, even though some certifications 
require on-going measurement and verification during the operation phase (e.g., Living Building Challenge, WELL, and others).

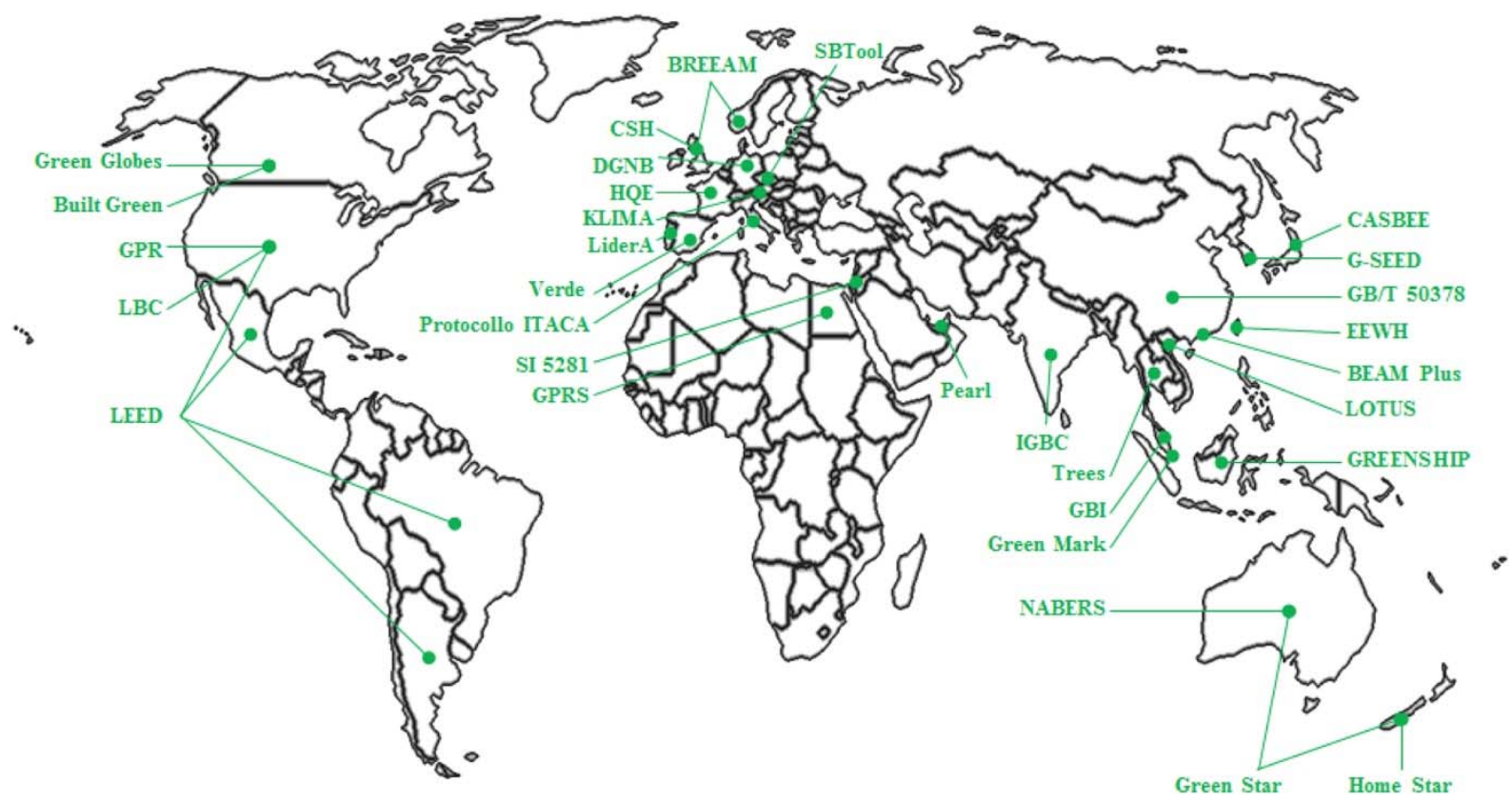

Figure 1 Map of the place of origin of Green Building Certifications (Source: Wei et. al. 2015 [5])

The most important indicators of whether a building is green or not should be its actual performance, not simply design intent, but this is only addressed in a few of the rating systems. Living Building Challenge certification is based on actual performance, rather than modeled or anticipated performance, and projects must be operational for at least 12 consecutive months prior to the final audit for certification [6]. The WELL Building Standard has large parts based on building conditions. An authorized WELL Assessor will usually spend one to three days in the building to validate the project's design documentation and to complete a series of performance tests, spot-checks and measurements spanning all WELL Concepts [7]. BOMA BEST, a unique, voluntary program designed by industry for industry, is Canada's largest environmental assessment and certification program for existing commercial real estate [8]. After the applicant 
completes a self-assessment questionnaire online, a third-party verifier will conduct an on-site visit to verify the answers and review the energy and water data as well as other documents; however, they are not required to conduct any on-site measurements. The Sustainability Tracking, Assessment \& Rating System ${ }^{\mathrm{TM}}\left(\mathrm{STARS}^{\circledR}\right)$ is a transparent, self-reporting framework for colleges and universities to measure their sustainability performance, created by Higher Education for Higher Education in the US beginning in 2010 [9]. An institution completes the STARS report online and submits it to the Association for the Advancement of Sustainability in Higher Education (AASHE), and then AASHE staff reviews portions of each report for accuracy and consistency. No further third-party verification or on-site visit is required. The National Australian Built Environment Rating Scheme (NABERS) is a national initiative managed by the Australian government that addresses the in-use energy efficiency, water usage, waste management and indoor environment quality of a building or tenancy and its impact on the environment [10]. The users can either use the free online calculator to get an idea of how well their building is performing or seek an accredited NABERS rating by finding a NABERS Accredited Assessor, who will collect and verify all the data for a rating according to the NABERS rules or validation protocols.

\subsection{Post Occupancy Evaluation}

To a large degree, the building industry's transition towards a green building perspective and mandate has been driven by the increasing adoption of green building certification systems, or at the very least by the way in which these systems impact design conversations (whether or not certification is actually pursued). But as noted, these certification systems focus primarily on 
the design phase and the design intent, with much less focus on the evidence of buildings' actual performance. The practice that best captures the assessment of actual building performance is Post Occupancy Evolution (POE), the general approach of obtaining feedback about a building's performance in use. While POE can be a part of a green building certification system or can be used in conjunction with certification systems, it is a distinct approach and set of techniques. This paper provides a survey of POE techniques and research. Previous work has introduced and reviewed POE [11-15] but has lacked a quantitative analysis of POE characteristics, applications, and trends. This paper presents a comprehensive and critical review to provide both a qualitative and a quantitative assessment of the state-of-the-art of POE projects and methodologies, including an evaluation of current research and potential future trends.

First, Section 2 summarizes the definition and benefits of POE. Then, Section 3 presents a literature analysis of 146 POE projects, including a descriptive statistical analysis of the types and countries of the buildings assessed to show the focuses of POE research, a content analysis of the purposes of the projects to develop a taxonomy, and a descriptive statistical analysis of the methods used to show the trends. Section 4 then summarizes and compares 13 existing POE protocols found from the literature and in practice that represent the status quo. Section 5 further identifies three emerging topics in current POE research. Finally, Section 6 discusses five directions for future POE.

\section{POE History, Definition, and Benefits}

An extensive literature review [16] stated that the history of modern-day POE methods dates back to the late 1960s, when Sim van der Rijn of the University of California, Berkeley, and 
Victor Hsia of the University of Utah conducted a systematic assessment of university dormitories from the occupants' point of view. After that, several similar evaluation projects were conducted, although not all were called POE. The first publication with the term "POE" in the title was authored by Herb McLaughlin of KMD Architecture in San Francisco in the AIA Journal issue of January 1975. The concept and terminology became more mainstream when, in 1988, Preiser, Rabinowitz and White wrote a POE textbook, where POE was defined as "the process of evaluating buildings in a systematic and rigorous manner after they have been built and occupied for some time" [17]. As POEs become broader in scope and purpose, in 2002 an industryaccepted definition of POE was stated as "any activity that originates out of an interest in learning how a building performs once it is built (if and how it has met expectations) and how satisfied building users are with the environment that has been created" [18].

In 1997, the concept of POE was expanded upon, when Preiser and Schramm proposed an integrated framework of building performance evaluation (BPE). In this framework, POE represents only one of the six internal review loops (Figure 2). BPE focuses on the entire life of the building, from planning, programming, design, construction, occupancy, to adaptive re-use or recycling. Although there is a trend to regard BPE as a new name for POE (and in some literature the definition of BPE is exactly the definition of POE), we acknowledge the difference between POE and BPE and will only focus on POE in this paper (i.e., the occupancy phase of a building's life cycle). 


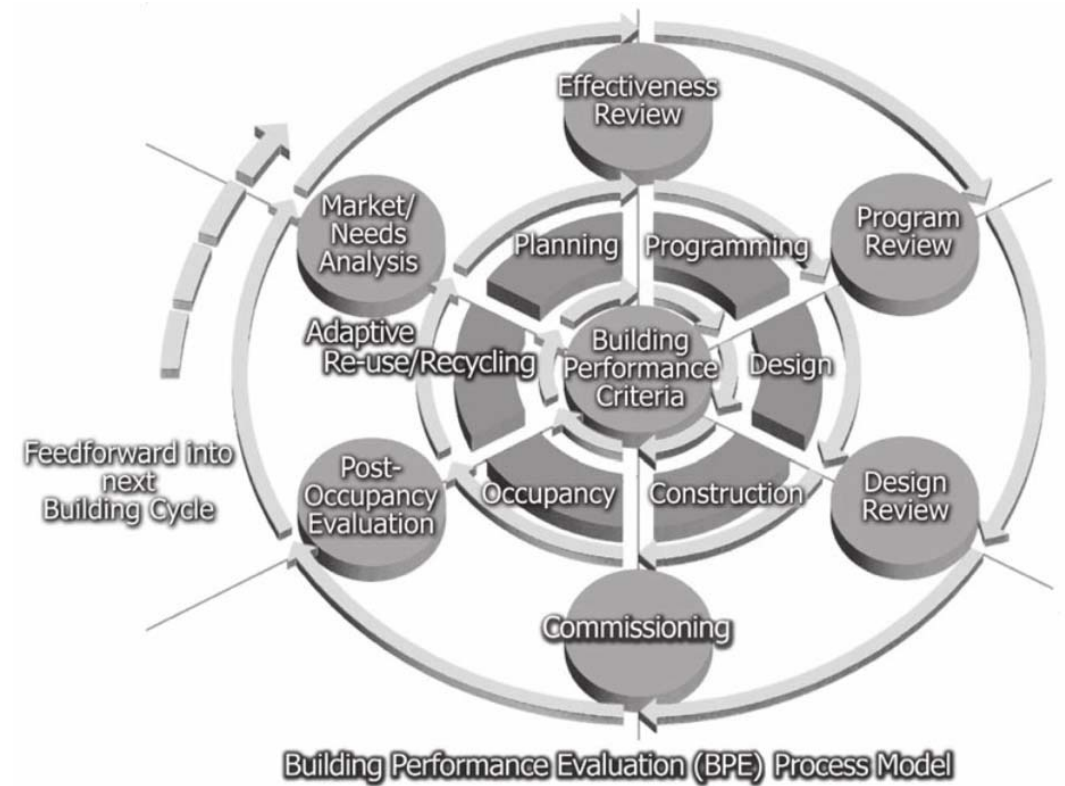

Figure 2 Building Performance Evaluation (BPE) Process Model (Source: Preiser 2005 [16])

POE plays an important role in the life-cycle of a building: feedback. POE offers a wide range of activities and benefits, including: assessment of building performance, exploration of relationships between inhabitant behavior and building resource use, optimization of the indoor environment for inhabitants, more informed decisions about future building design, and opportunities to enhance the dialogue within design teams and their partners $[19,20]$.

\section{POE Projects}

This section provides a comprehensive state-of-the-art review of POE projects worldwide. Searching "post-occupancy evaluation" in the topic field (which includes title, abstract, and key words) in the Web of Science index generated 382 results as of September 2017. The blue line in Figure 3 shows that the number of POE-related publications increased dramatically around 2010. Therefore, the authors decided to review the 269 publications from 2010 to 2017, which represent the majority and more recent POE studies. Out of the 269 publications, the authors 
identified 146 POE projects (the orange line in Figure 3) and recorded the key information of those POE projects in Excel for later statistical analysis in Tableau. In this paper, a "POE project" refers to a research project or practitioner investigation of building(s) in the real world using POE methods. We excluded publications that were reviews rather than original research, not in English, not available online, or not for buildings (e.g., landscape, park, garden, a single system, etc.). A "POE project" can investigate more than one building and can be described in more than one publication. As long as the publications described the same POE results of the same building(s) (but perhaps from different perspectives), we counted those publications as one project. In any project where questionnaires were distributed to a large set of people without specifying how many buildings were assessed, we attributed only one building to this project. This section describes the quantitative and qualitative analysis of the 146 POE projects.

POE Literature Search

(Web of Science Search Results,

"Post-occupancy evaluation", as of Sept. 25th, 2017)

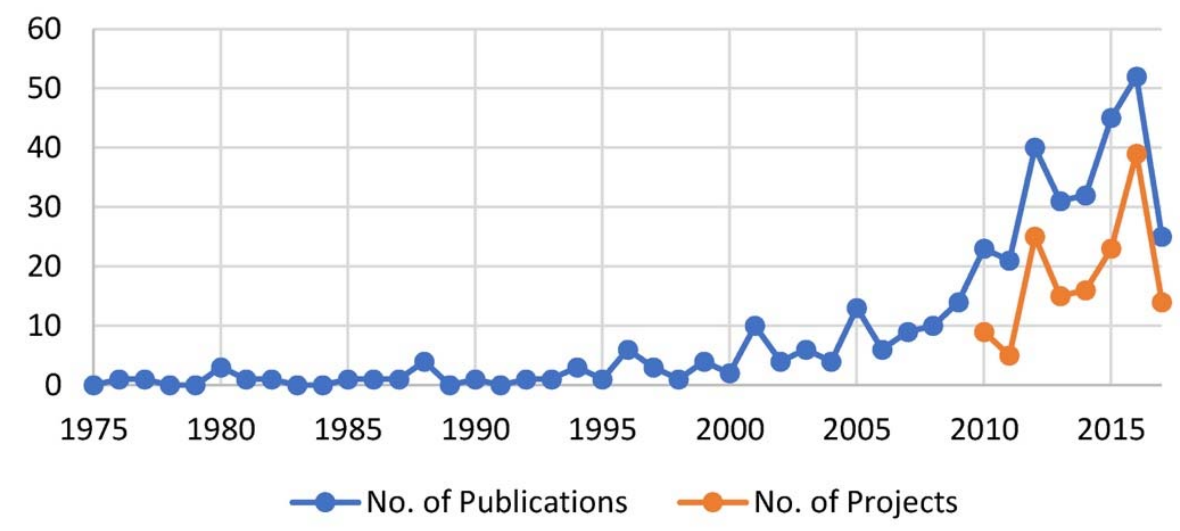

Figure 3 Number of POE publications and POE projects 


\subsection{Buildings Assessed: Types and Countries}

Starting with the list of building types on Wikipedia, we modified the categories slightly

(e.g., separated offices from the more general category of commercial buildings) with the aim of showing the research focuses clearly. In this paper, building types are defined as follows:

- Commercial building: including supermarkets, clubs, convention centers, etc.

- Office: including office buildings and those mixed-use commercial buildings where the focus of the POE research was the office area.

- University building: including sport center, canteen, cafeteria, and others with multiplefunctions in universities.

- Educational building: including kindergarten, school, preschool, child care, library, and gallery.

- Medical building: including hospital, healthcare, and cancer support center.

- Residential building: including house, apartment, flat, dwelling unit, villa, and dormitory.

- Transport building: including railway station and airport terminal building.

- Government building: including court, museum, and post office.

In many cases, a POE project evaluated more than one building. Thus, Figure 4 shows both the number of projects and number of buildings, organized by building type. We found that residential buildings were the most popular research targets, followed by office, university buildings and educational buildings. This is not a surprise since these buildings are where people spend most of their time: living, working, and studying. 
POEs for different types of building are often very different in terms of both their purpose and methodology. POEs of residential buildings often focus on occupants' experience and use of facilities, and therefore, almost every project would use an occupant survey or interview as the research method. POEs of office buildings are typically interested in occupants' comfort and productivity, and the more sophisticated of these would utilize both a survey and physical measurements of indoor environment quality (IEQ). POEs of university building are variable but, depending on the objective, could be similar to the POEs of either office or residential buildings. POEs of kindergartens and schools usually focus on the efficiency of teaching activities, sometime including the analysis of children's behaviors, and thus, observation is the key component of the methodology. POEs of medical buildings are typically quite distinct from other POEs: on one hand, they use variable methods to evaluate the general user experience (e.g., accessibility and wayfinding); on the other hand, medical buildings have strict requirements on IEQ (e.g., sound insulation and indoor air quality (IAQ) of wards, which would require in-situ physical measurement of IEQ). 
Building Type

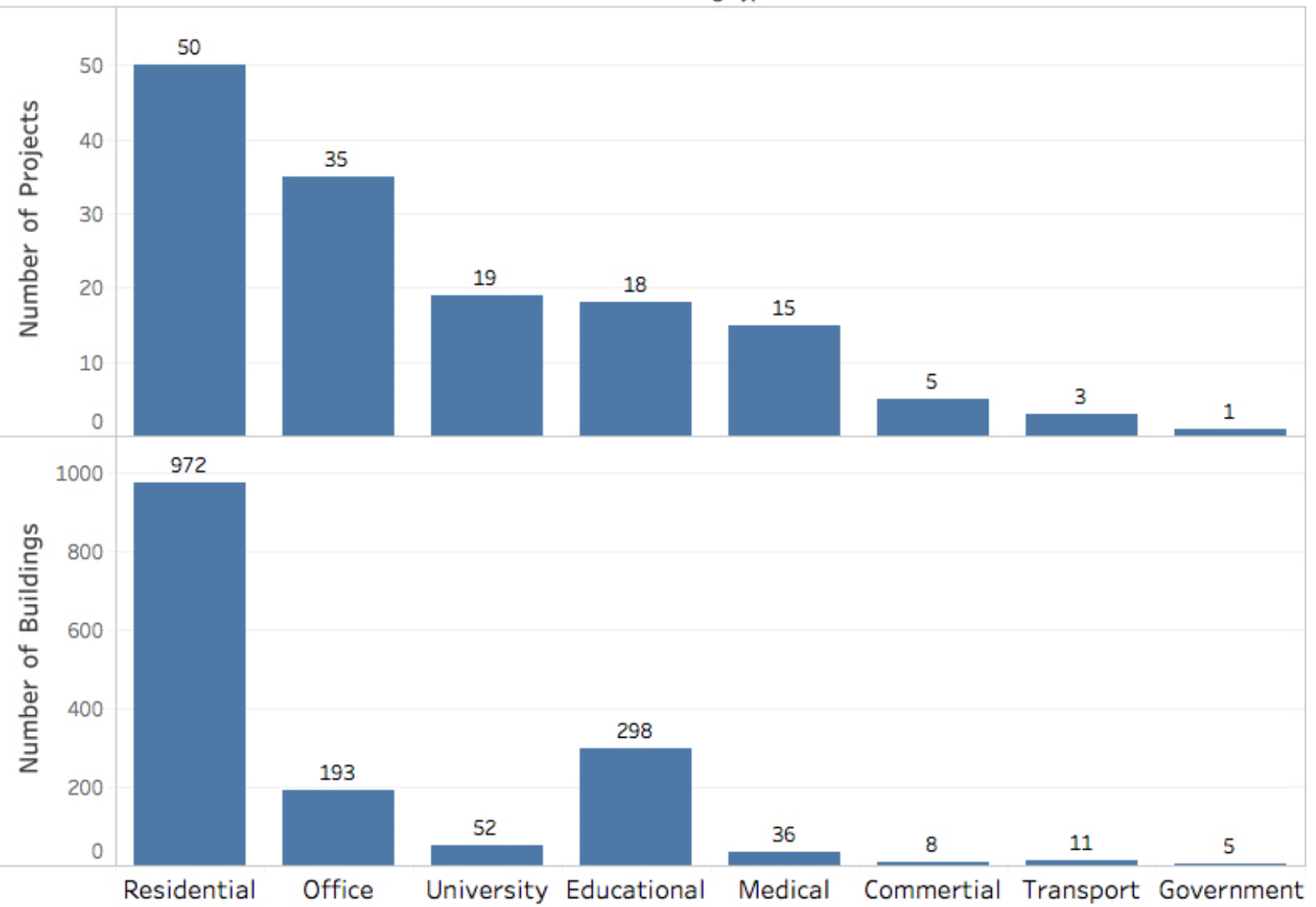

Figure 4 Number of projects and number of buildings per type of building

We also recorded the country in which the buildings were assessed, again in terms of both number of projects and buildings. Figure 5 and Figure 6 show that the UK, the US, China, Australia, Canada and Malaysia are more active in POE research. 


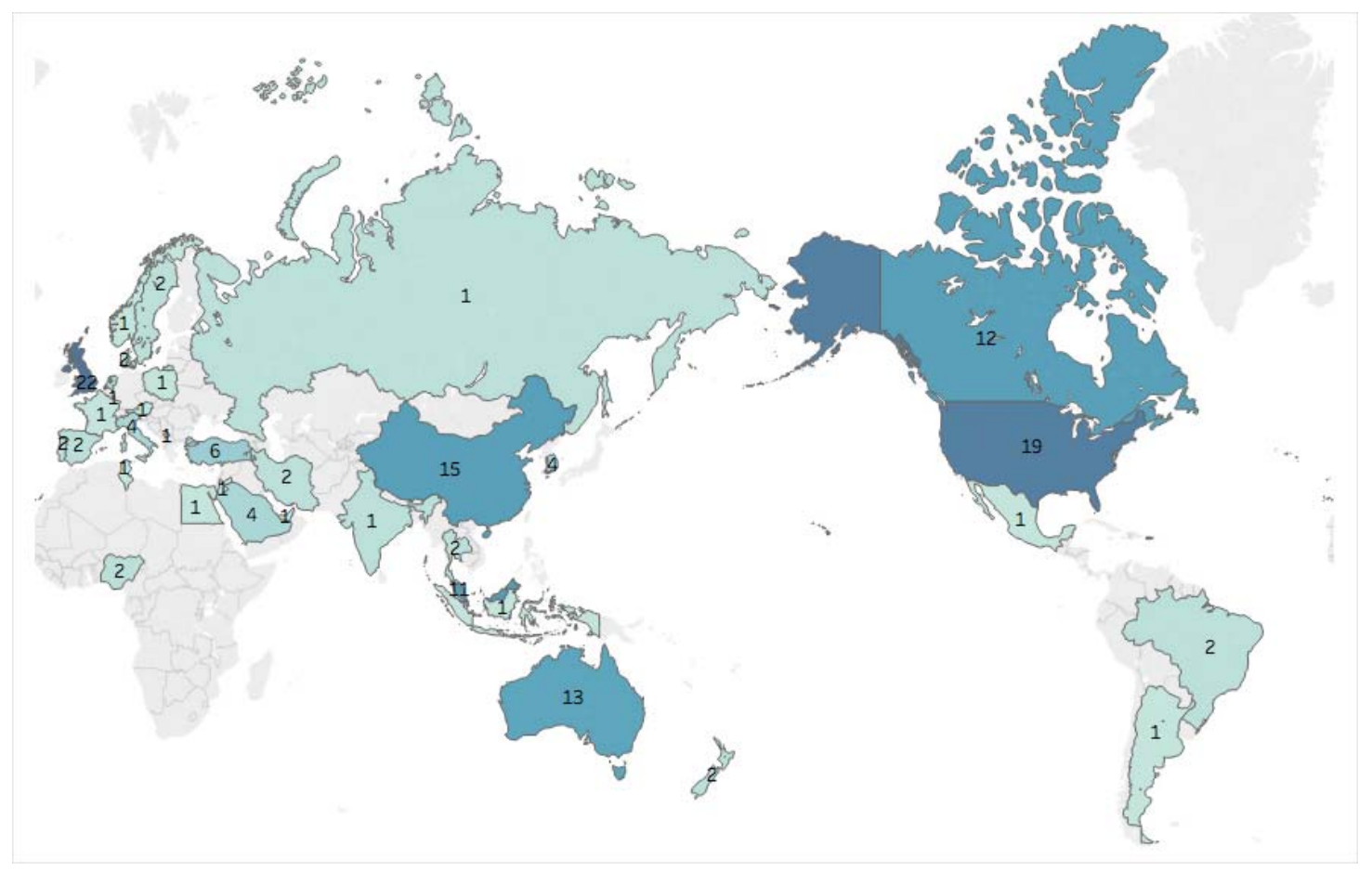

Figure 5 Number of projects per country

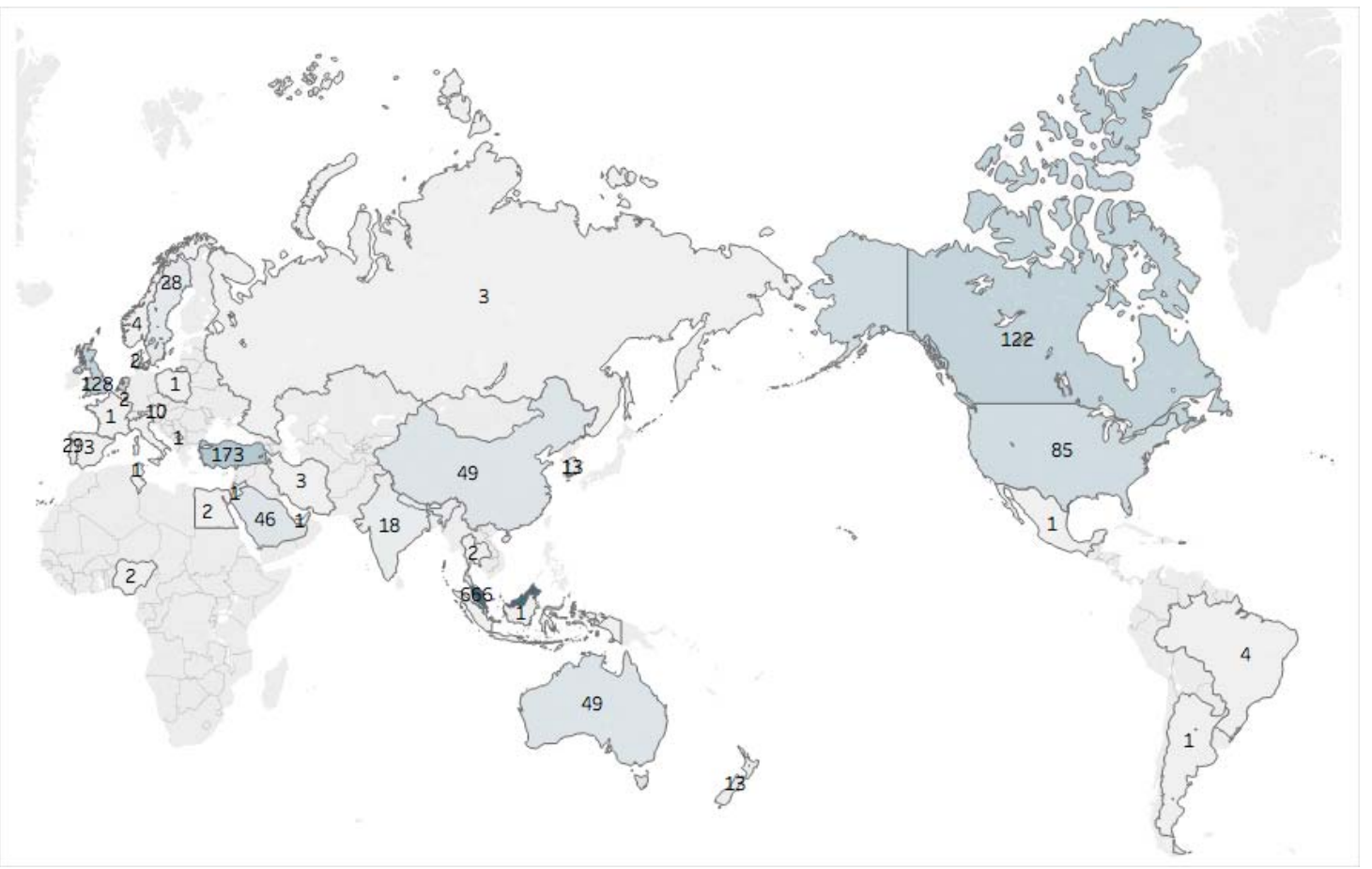

Figure 6 Number of buildings assessed per country 


\subsection{Purposes}

POE projects are conducted for numerous purposes. Preiser, in 1995, classified three levels of POE: indicative, investigative and diagnostic [21]. In 2008, Hadjri and Crozier stated that "the overarching notion of the purpose of $\mathrm{POE}$ is to facilitate the accumulation of information/knowledge that can be subsequently utilised to improve the procurement of buildings to the benefit of all the stakeholders involved" [14]. Although much has been written about POE, the literature still lacks a systematic review and nuanced typology of the purposes.

The authors used voyant-tools.org to analyze the word frequency of the recorded purposes of the 146 projects (Table 1).

Table 1 Top 20 frequent words in the purposes of POE projects

\begin{tabular}{|c|c|c|c|c|c|}
\hline Frequency Rank & Word & Count & Frequency Rank & Word & Count \\
\hline 1 & building(s) & 46 & 11 & use & 14 \\
\hline 2 & performance & 27 & 12 & design & 13 \\
\hline 3 & occupant(s) & 24 & 13 & investigate & 13 \\
\hline 4 & evaluate & 20 & 14 & comfort & 12 \\
\hline 5 & energy & 19 & 15 & quality & 12 \\
\hline 6 & environment(al) & 19 & 16 & green & 10 \\
\hline 7 & user(s) & 19 & 17 & IEQ & 10 \\
\hline 8 & satisfaction & 18 & 18 & post & 10 \\
\hline 9 & assess & 14 & 19 & occupancy & 10 \\
\hline 10 & indoor & 14 & 20 & thermal & 9 \\
\hline
\end{tabular}


The word frequency test shows that POE projects aim to evaluate, assess, or investigate the buildings' performance, for the purpose of learning about occupant response, energy use, physical IEQ, performance of specific design features, etc. Some of these words were simply describing the process, while others were more focused on what the investigators were trying to learn. In making this distinction, the authors propose a hierarchy to categorize the POE purposes as summarized in Table 2, and described further below.

Table 2 Classification of POE Purposes

\section{Purposes Description with examples from the literature}

\section{Level 1: Direct Purposes}

Evaluate Design $\quad$ To examine design innovations [22], design features for certain group of occupants [2325], or the design process of a project [26].

Evaluate Occupants To evaluate occupants' comfort, satisfaction, well-being, or health [27-31]; investigate the factors that affect their satisfaction [32-34]; understand their opinions or experiences of a space [35-38]; assess their productivity [39,40]; understand occupant behavior [41$45]$; assess occupant opinions of green building rating tools $[46,47]$; or evaluate the sociality of occupants [48].

Evaluate Energy To understand the energy use, usually in a case with energy retrofit, renovation, or Performance $\quad$ energy-saving strategy [49-51]; or for benchmarking [52].

Evaluate IEQ To measure one or more physical characteristics of IEQ: thermal condition [53,54], lighting $[55,56]$, indoor air quality [57], acoustics [58].

Evaluate Facility To assess the quality and functionality of facilities [59-62], safety performance [63], or to inform the maintenance management $[64,65]$.

Level 2: Indirect Purposes 


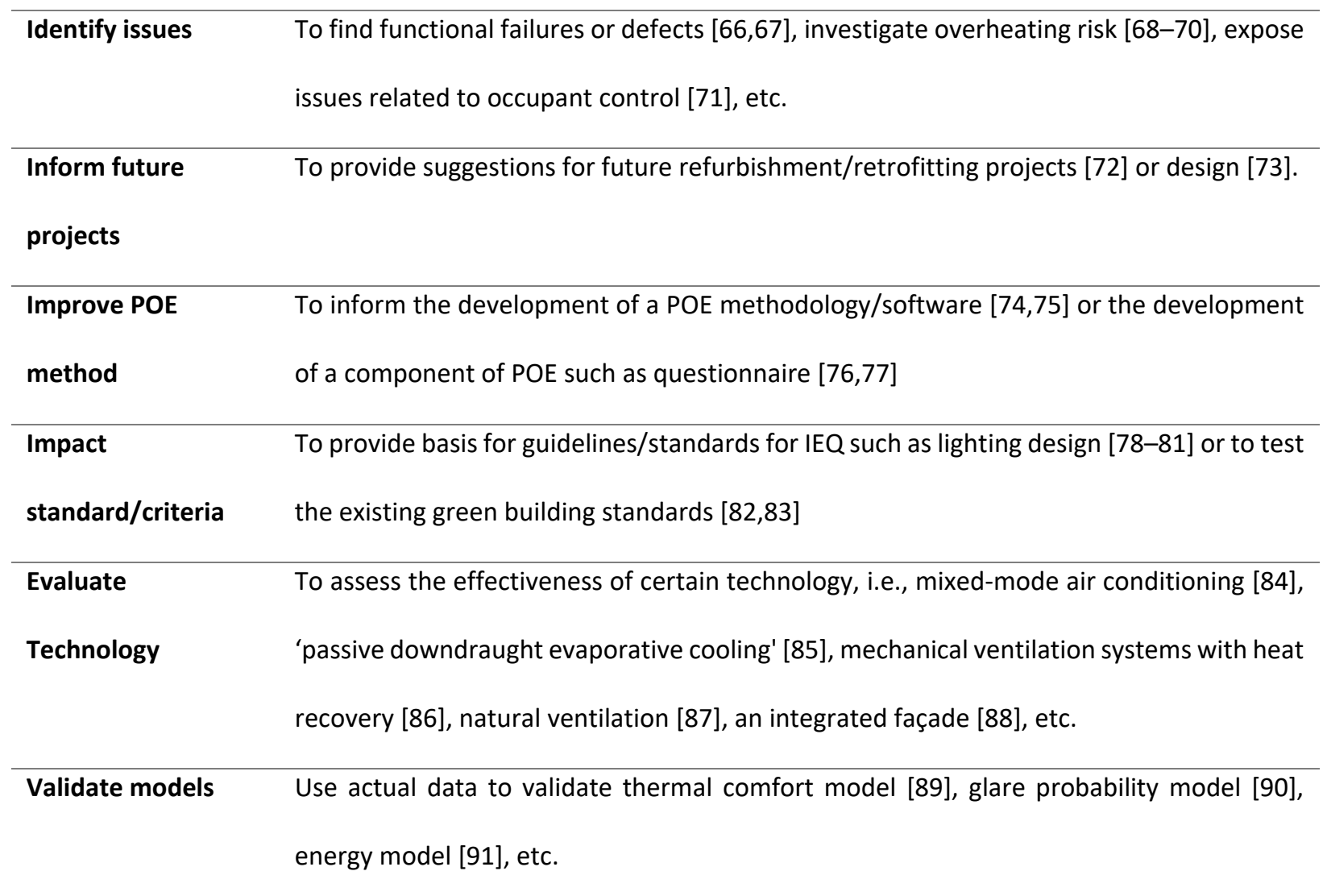

Level 1, "Direct Purpose", includes the direct evaluation, measurement, or assessment of the topic in question, including the design, occupants, energy performance, IEQ and facilities. A POE project could, and usually does, have several level 1 purposes, e.g., investigate effects of IEQ on occupants' comfort [92,93], reveal relationships between human factors and IEQ satisfaction [94], evaluate the impact of design features on well-being outcomes [95], etc. Figure 7 shows the concurrence of level 1 purposes, where the area of the circles and intersections indicate the relative number of projects found in this literature review. The most common focus of a POE evaluation is on the occupant, followed by IEQ, energy, design and facility. 


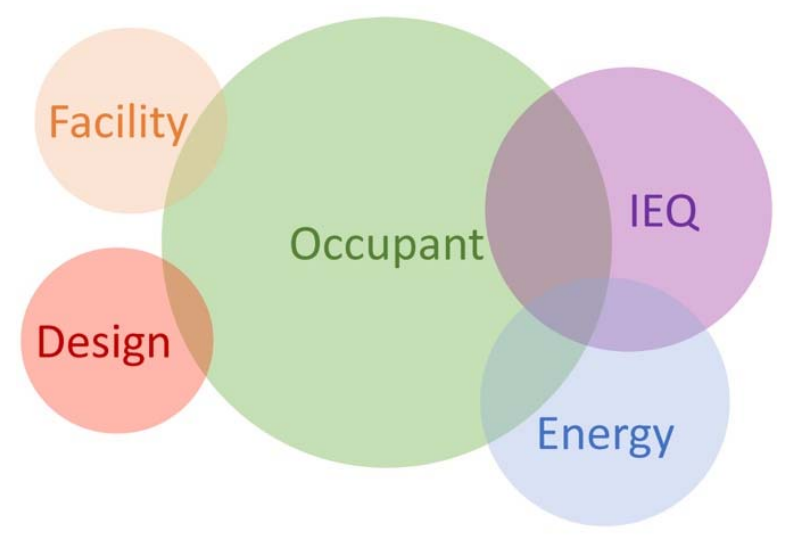

Figure 7 Venn Diagram of POE Direct Purposes

Level 2, "Indirect purpose", relates to the question "why POE", or what ultimate impact is one trying to have. A project could have more than one indirect purposes as well. By evaluating one or more aspects of a building, a POE project usually aims to contribute to a body of knowledge about the individual building or, ideally, to generalize lessons learned for a broader application. These could include identifying issues, design strategies, or problems that affect building performance, influencing future projects by helping design teams and owners make more informed decisions, improving future POE methods, impacting building standards or green rating systems, evaluating the effectiveness of technologies, or validating predictive models.

Of the projects we investigated, nearly $30 \%$ were intended for some sort of comparison, although we did not categorize comparison as its own separate purpose. Of these: 12 projects compared the actual performance to predicted performance from models, simulation or targets; 16 projects involved comparison between green building performance and non-green building performance (including specific features such as natural ventilation); six projects compared occupants' satisfaction to benchmark results; and five projects compared IEQ measurements to 
standard requirements. Other comparisons included pre- vs. post-retrofit, and new vs. old homes or facilities.

\subsection{Methods}

POE methods can broadly include energy and water assessment, IEQ physical measurements, occupant survey questionnaires, focus group meetings, structured interviews, visual records, walkthroughs, and technical measurement of building structure, services and systems $[11,13]$. A few projects used window opening sensors or GPS-enabled mobility tracking to study occupant behaviors. For the 146 projects studied, we used the following categories to track the use of the most common methods:

- Subjective methods

o Occupant survey: including standardized occupant satisfaction survey, thermal comfort survey, visual comfort survey, and in most of the cases, customized surveys. These can include questions that inquire about "how do you feel right now" or "general satisfaction".

o Interview: including structured or semi-structured interviews and focus group meetings, usually with occupants, sometimes with experts.

o Walkthrough: including expert tours meant to identify issues, usually along with photo/video recording, design/condition checklists, and observation forms.

- Physical measurements 
o IEQ in-situ measurements:

- Thermal condition (infrared thermal imaging, sensors/meters for temperature, relative humidity, air velocity, etc.)

- Lighting (illuminance and luminance meters, high dynamic range (HDR) imaging cameras)

- IAQ (sensors for $\mathrm{CO}_{2}$ concentrations, VOC, formaldehyde, $\mathrm{CO}$, respirable particles, etc.)

- Acoustics (sound level meters, reverberation test)

o Energy: assessed via audit, sensors, meters or bills.

o Water: assessed via meters or bills.

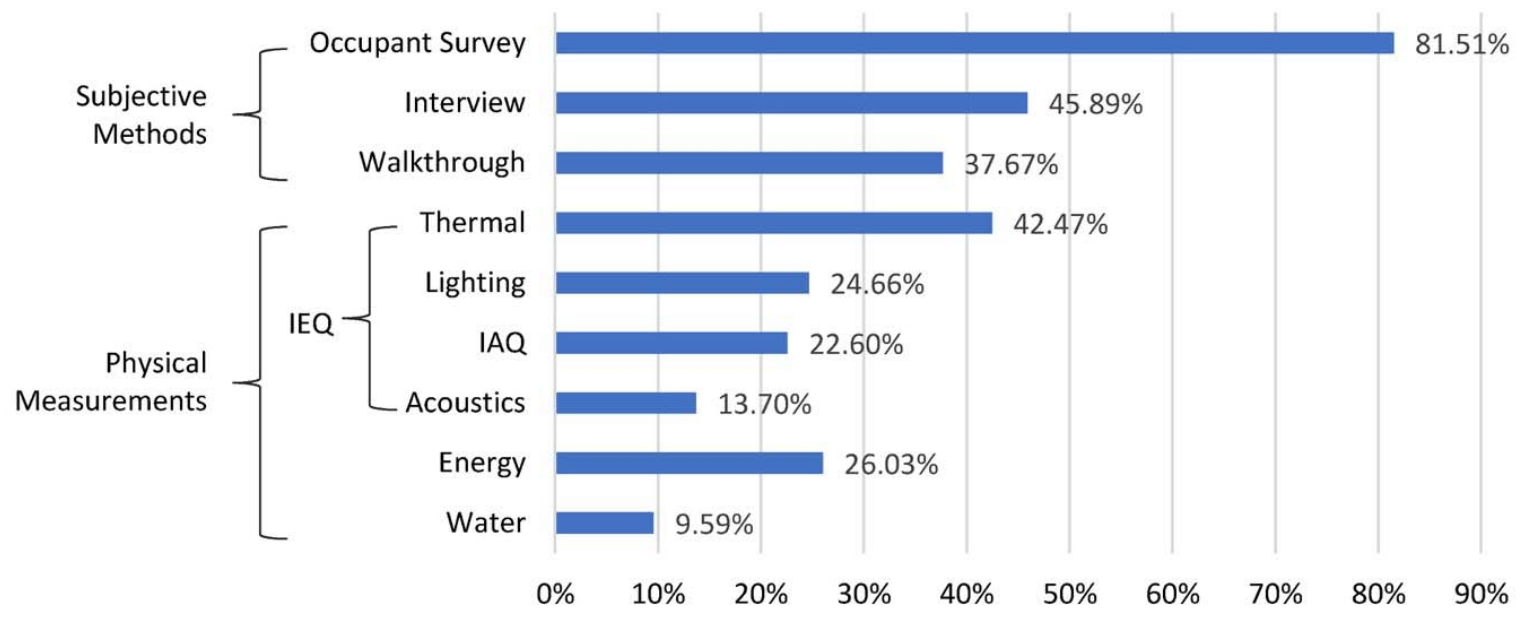

Figure 8 Percentage of projects that used certain method (note that most projects used more than one method)

As Figure 8 shows, occupant survey is the most widely used method ( $81.51 \%$ of projects), probably because it could help quantify subjective opinions through the use of questions with scaled responses, and then benchmark the results. In general, subjective methods like walkthrough, interviews and surveys (which might include qualitative, open-ended questions) 
are more commonly used because they are inexpensive (no need for equipment associated with physical measurements) and they can help identify problems quickly. In terms of IEQ in-situ measurements, $42.47 \%$ of the projects measured thermal conditions, while only $13.70 \%$ of the projects measured acoustic condition, which substantiates a common understanding in the industry that acoustics is a relatively "ignored" area of IEQ. However, even fewer projects (less than $10 \%$ ) measured water consumption, and there is not much attention paid to energy (only $26 \%$ of projects calculated energy consumption). This is most likely simply a result of the literature review methods, where we used "post-occupancy evaluation" as the key word, and many research projects that evaluate energy performance separate from occupant issues will not likely use that phrase.

In order to explore the trends in the use of these methods, we plotted the percentage of projects that used each of the methods every year (Figure 9). No explicit trends were recognized except for energy measurement and survey. As Figure 9 shows, energy is fading from POE research, again perhaps just representing a trend in the term "POE" being used for such research. In contrast, the occupant survey is gradually becoming a must for a POE project, confirming that there is increasing attention being paid in the building industry on issues of occupant health and wellbeing. In addition, while water and acoustics measurements are the least used methods, it seems that the attention on acoustics is increasing in recent years while that on water is decreasing. Nevertheless, these trends are not statistically significant and this variability may relate largely to the sets of keywords selected for this literature review. 


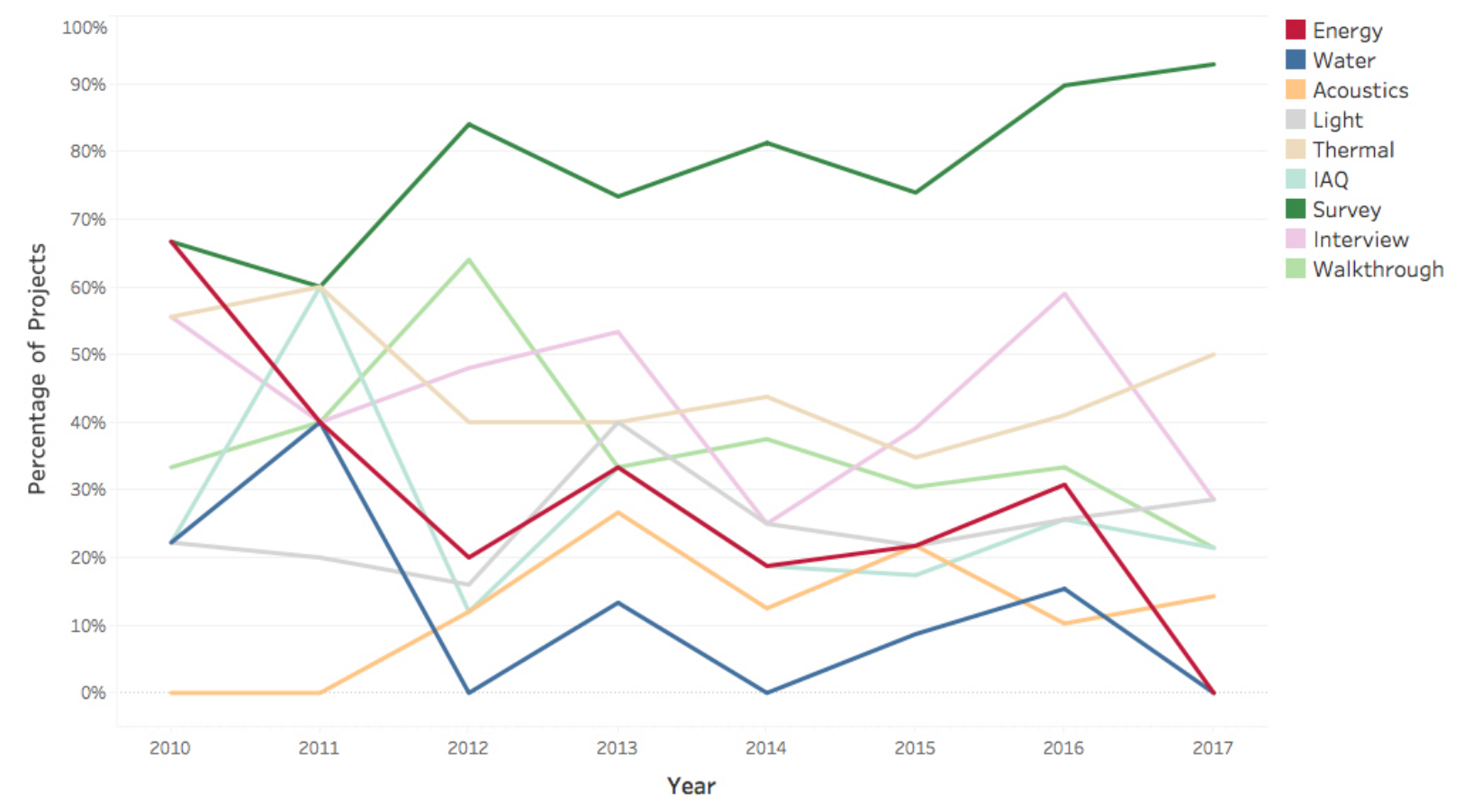

Figure 9 Trends of the usage of POE methods

\section{POE Protocols}

Some of the papers we reviewed examined the overall performance of the buildingincluding energy, occupants, IEQ and more-with a systematic methodology. For these studies, we call the package of POE methods a "protocol", and Table 3 provide a brief comparison of 13 existing POE protocols we found from the literature and in practice. The "year" either means the year in which the protocol was first developed, or the year of the first related publication (if the year of development is unknown). 


\begin{tabular}{|c|c|c|c|c|c|c|c|}
\hline POE protocol & Ref. & Year & Developer & Country & $\begin{array}{l}\text { Building } \\
\text { Type }\end{array}$ & Aspects Evaluated & Notes \\
\hline $\begin{array}{l}\text { Post-Occupancy } \\
\text { Review of } \\
\text { Building } \\
\text { Engineering } \\
\text { (PROBE) }\end{array}$ & $\begin{array}{l}{[96,9} \\
7]\end{array}$ & 1995 & $\begin{array}{l}\text { Energy for } \\
\text { Sustainable } \\
\text { Development, } \\
\text { William Bordass } \\
\text { Associates, } \\
\text { Building Use } \\
\text { Studies, Target } \\
\text { Energy Services }\end{array}$ & UK & Varied & $\begin{array}{l}\text { - Energy audit by Office Assessment Method } \\
\text { (OAM) } \\
\text { - BUS occupant survey } \\
\text { - Design and Construction } \\
\text { - Maintainability } \\
\text { - Control Issues } \\
\text { - Review of performance }\end{array}$ & $\begin{array}{l}\text { - Methods used may } \\
\text { be different for the } \\
23 \text { case studies. } \\
\text { - One report for one } \\
\text { case study. }\end{array}$ \\
\hline $\begin{array}{l}\text { CBE Building } \\
\text { Performance } \\
\text { Evaluation (BPE) } \\
\text { toolkit }\end{array}$ & $\begin{array}{l}\text { [98], } \\
{[99]}\end{array}$ & 2000 & $\begin{array}{l}\text { Center for the } \\
\text { Built } \\
\text { Environment } \\
\text { (CBE) at UC } \\
\text { Berkeley }\end{array}$ & US & Commercial & $\begin{array}{l}\text { - Occupant IEQ satisfaction survey about } \\
\text { thermal comfort, air quality, acoustics, } \\
\text { lighting, cleanliness, spatial layout, and } \\
\text { office furnishings } \\
\text { - Indoor Climate Monitor (ICM): device with } \\
\text { sensors for } \mathrm{CO}_{2} \text {, illuminance, globe } \\
\text { temperature, air velocity, dry bulb } \\
\text { temperature, and RH } \\
\text { - Portable UFAD Commissioning Cart (PUCC): } \\
\text { measure T at many levels for a space that is } \\
\text { conditioned by a stratified system such as } \\
\text { an underfloor air distribution system } \\
\text { (UFAD) } \\
\text { - Sound level pressure meter }\end{array}$ & $\begin{array}{l}\text { - Web-based survey } \\
\text { with online reporting } \\
\text { - Software and } \\
\text { hardware to support } \\
\text { PMP-based IEQ } \\
\text { analysis } \\
\text { - GIS-enabled floor } \\
\text { plan maps } \\
\text { - Scorecard and report } \\
\text { generation tool }\end{array}$ \\
\hline NEAT & $\begin{array}{l}{[81,1} \\
00,10 \\
1]\end{array}$ & 2003 & $\begin{array}{l}\text { Center for } \\
\text { Building } \\
\text { Performance and } \\
\text { Diagnostics at } \\
\text { Carnegie Mellon } \\
\text { University }\end{array}$ & US & Office & $\begin{array}{l}\text { - Electricity and gas bills } \\
\text { - IEQ snap-shot: NEAT cart to measure T, RH, } \\
\mathrm{CO}_{2}, \mathrm{CO}, \mathrm{PM} \text { and TVOC; hand-held sensors } \\
\text { to measure light levels, radiant } \\
\text { temperature, air velocity, and noise level } \\
\text { - Occupant: Cost-effective Open-Plan } \\
\text { Environments (COPE) environmental } \\
\text { satisfaction questionnaire, a long-term } \\
\text { survey, and interviews } \\
\text { - Technical Attributes of Building Systems } \\
\text { documenting }\end{array}$ & $\begin{array}{l}\text { - NEAT cart provides } \\
\text { automatic data } \\
\text { logging. } \\
\text { - NEAT interface has } \\
\text { been developed. }\end{array}$ \\
\hline
\end{tabular}




\begin{tabular}{|c|c|c|c|c|c|c|c|}
\hline & & & & & & $\begin{array}{l}\text { - Thermal envelope evaluated by } \\
\text { thermographic camera }\end{array}$ & \\
\hline $\begin{array}{l}\text { Whole Building } \\
\text { Cost and } \\
\text { Performance } \\
\text { Measurement }\end{array}$ & [102] & 2005 & $\begin{array}{l}\text { Pacific } \\
\text { Northwest } \\
\text { National } \\
\text { Laboratory }\end{array}$ & US & $\begin{array}{l}\text { All (for } \\
\text { Federal } \\
\text { sector) }\end{array}$ & $\begin{array}{l}\text { - Water } \\
\text { - Energy } \\
\text { - Maintenance \& Operations } \\
\text { - Waste Generation and Recycling } \\
\text { - IEQ } \\
\text { - Transportation } \\
\text { - For each aspect above, metrics are } \\
\text { identified as required and optional. } \\
\text { - Building and Site Characteristics are } \\
\text { collected first to filter buildings, allowing a } \\
\text { valid comparison. }\end{array}$ & $\begin{array}{l}\text { - Published the second } \\
\text { version in } 2009 \\
\text { - Recommend data } \\
\text { visualization charts } \\
\text { - Disclose the selection } \\
\text { criteria of the metrics }\end{array}$ \\
\hline EcoSmart & [103] & 2005 & $\begin{array}{l}\text { Stantec } \\
\text { Consulting Ltd. } \\
\text { (formerly Keen } \\
\text { Engineering) }\end{array}$ & Canada & Varied & $\begin{array}{l}\text { - } 14 \text { Components: } \\
\text { Kick-off discussion with Owner, Kick-off } \\
\text { discussion with design team, Energy } \\
\text { Consumption, Water Consumption, } \\
\text { Information from building operator, } \\
\text { Information from Occupants (web-based } \\
\text { survey), Information from Occupants } \\
\text { (Qualitative), Washroom and Washroom } \\
\text { Fixture Evaluation, Indoor Air Quality } \\
\text { Measurements, Lighting Measurements, } \\
\text { Acoustic Measurements, Thermal Comfort } \\
\text { Measurements, Wrap-up discussion with } \\
\text { design team and occupant representatives, } \\
\text { Process Reflection and Conclusions. }\end{array}$ & $\begin{array}{l}\text { - Available in Excel } \\
\text { format } \\
\text { - For each component, } \\
\text { the protocol defines } \\
\text { whether it is required } \\
\text { or optional, explains } \\
\text { the purpose, the } \\
\text { evaluator skills, } \\
\text { participants in } \\
\text { discussion, time } \\
\text { required, and cost. } \\
\text { - CBE occupant } \\
\text { satisfaction survey } \\
\text { and CBE operator } \\
\text { survey are } \\
\text { recommended. }\end{array}$ \\
\hline $\begin{array}{l}\text { Performance } \\
\text { Measurement } \\
\text { Protocol (PMP) }\end{array}$ & [104] & 2010 & $\begin{array}{l}\text { ASHRAE, USGBC, } \\
\text { CIBSE }\end{array}$ & US & Commercial & $\begin{array}{l}\text { - Energy and water use } \\
\text { - IEQ measurements: thermal comfort, } \\
\text { acoustics, IAQ, lighting/daylight } \\
\text { - Occupant surveys: CBE survey is } \\
\text { recommended. } \\
\text { - Three levels-Basic (indicative), } \\
\text { Intermediate (diagnostic), and Advanced }\end{array}$ & $\begin{array}{l}\text { - Articulates what } \\
\text { should be measured, } \\
\text { measurement } \\
\text { methods and their } \\
\text { cost, recommended } \\
\text { indicators, industry } \\
\text { standards, and } \\
\text { benchmarks. }\end{array}$ \\
\hline
\end{tabular}




\begin{tabular}{|c|c|c|c|c|c|c|c|}
\hline & & & & & & $\begin{array}{l}\text { (investigative). Each level measures the six } \\
\text { aspects to different details. }\end{array}$ & \\
\hline $\begin{array}{l}\text { Creative Energy } \\
\text { Homes (CEH) }\end{array}$ & $\begin{array}{l}{[75,1} \\
05]\end{array}$ & 2010 & $\begin{array}{l}\text { University of } \\
\text { Nottingham }\end{array}$ & UK & Residential & $\begin{array}{l}\text { - Electricity (individual power circuits and } \\
\text { appliance meters), water use, energy and } \\
\text { heat meters } \\
\text { - IEQ monitoring: sensors for T, RH, air } \\
\text { quality } \\
\text { - Occupancy patterns and space use } \\
\text { monitoring using a real-time location } \\
\text { tracking system (ultra-wideband radio } \\
\text { frequency) }\end{array}$ & $\begin{array}{l}\text { - Every CEH house has } \\
\text { smart monitor system } \\
\text { and display screens } \\
\text { installed. } \\
\text { - Developed software } \\
\text { to process data }\end{array}$ \\
\hline $\begin{array}{l}\text { Building } \\
\text { Occupants } \\
\text { Survey System } \\
\text { Australia } \\
\text { (BOSSA) }\end{array}$ & [106] & 2011 & $\begin{array}{l}\text { University of } \\
\text { Sydney, } \\
\text { University of } \\
\text { Technology } \\
\text { Sydney }\end{array}$ & Australia & Office & $\begin{array}{l}\text { - IEQ snap-shot: BOSSA Nova cart to measure } \\
\text { T, air velocity, } \mathrm{RH}, \mathrm{CO}, \mathrm{CO}_{2}, \mathrm{TVOC} \\
\text { formaldehyde, ambient sound, and } \\
\text { illuminance } \\
\text { - Occupant: BOSSA Time-lapse survey, BOSSA } \\
\text { Snap-shot surveys, about } 9 \text { IEQ dimensions }\end{array}$ & $\begin{array}{l}\text { - Online survey results } \\
\text { populated the BOSSA } \\
\text { database. }\end{array}$ \\
\hline NRCC & $\begin{array}{l}{[107,} \\
108]\end{array}$ & 2012 & $\begin{array}{l}\text { National } \\
\text { Research Council } \\
\text { Canada (NRCC) }\end{array}$ & Canada & Office & $\begin{array}{l}\text { - Energy: whole building utility bills (sub- } \\
\text { systems \& water, if available) } \\
\text { - IEQ snap-shot: HDR photography and the } \\
\text { NICE (National Research Council Indoor } \\
\text { Climate Evaluator) cart to measure T, air } \\
\text { speed, RH, formaldehyde, } \mathrm{CO}_{2}, \mathrm{CO}, \mathrm{PM} \text {, } \\
\text { illuminance, luminance and sound pressure } \\
\text { (third-octave bands) } \\
\text { - IEQ monitoring: the "Pyramids" to collect a } \\
\text { subset of IEQ parameters collected by the } \\
\text { cart for several days } \\
\text { - On-line questionnaire about environmental } \\
\text { satisfaction, job satisfaction, health, } \\
\text { absenteeism, environmental attitudes, } \\
\text { commuting patterns } \\
\text { - Interview with building manager }\end{array}$ & $\begin{array}{l}\text { - } 12 \text { pairs of green and } \\
\text { non-green buildings } \\
\text { were matched based } \\
\text { on building } \\
\text { characteristics. }\end{array}$ \\
\hline $\begin{array}{l}\text { International } \\
\text { Institute for a } \\
\text { Sustainable Built }\end{array}$ & $\begin{array}{l}{[109,} \\
110]\end{array}$ & 2014 & $\begin{array}{l}\text { Ryerson } \\
\text { University, } \\
\text { University of } \\
\text { British Columbia, }\end{array}$ & Canada & All & $\begin{array}{l}\text { - Energy and water bills or meters } \\
\text { - IEQ snap-shot of lighting, thermal, acoustics } \\
\text { and air quality }\end{array}$ & $\begin{array}{l}\text { - For each aspect, } \\
\text { three types of } \\
\text { performance data } \\
\text { were collected: }\end{array}$ \\
\hline
\end{tabular}




\begin{tabular}{|c|c|c|c|c|c|c|}
\hline $\begin{array}{l}\text { Environment } \\
\text { (iiSBE) protocol }\end{array}$ & & $\begin{array}{l}\text { University of } \\
\text { Manitoba }\end{array}$ & & & $\begin{array}{l}\text { - Occupant survey based on the survey of } \\
\text { NRCC } \\
\text { - Interviews with owners/managers } \\
\text { - Structured walkthrough with building } \\
\text { managers } \\
\text { - Design documents review }\end{array}$ & $\begin{array}{l}\text { Actual, Predicted, and } \\
\text { Reference values or } \\
\text { benchmarks for } \\
\text { typical buildings of } \\
\text { similar use in the } \\
\text { region. }\end{array}$ \\
\hline $\begin{array}{l}\text { A Diagnostic } \\
\text { POE Model for } \\
\text { an Emergency } \\
\text { Department }\end{array}$ & 2014 & $\begin{array}{l}\text { Guinther, } \\
\text { Lindsey; Carll- } \\
\text { White, Allison; } \\
\text { Real, Kevin }\end{array}$ & US & Medical & $\begin{array}{l}\text { - IEQ snap-shot: sound and lighting level } \\
\text { meters } \\
\text { - Occupant: Behavioral Mapping, Occupancy } \\
\text { counts, Staff Questionnaire, Patient and } \\
\text { Visitor Questionnaire, Focus groups, } \\
\text { Interviews } \\
\text { - Use of space: Walkability Studies, Waiting } \\
\text { Times, the frequency of using equipment, } \\
\text { etc. }\end{array}$ & $\begin{array}{l}\text { Phase } 1 \text { and Phase } 2 \\
\text { data collection, each } \\
\text { with a set of } \\
\text { methods. }\end{array}$ \\
\hline $\begin{array}{l}\text { POE framework [111] } \\
\text { for higher } \\
\text { education } \\
\text { residence halls }\end{array}$ & 2015 & $\begin{array}{l}\text { Alborz, Nakisa; } \\
\text { Berardi, } \\
\text { Umberto }\end{array}$ & $\begin{array}{l}\text { US, } \\
\text { Canada }\end{array}$ & Residential & $\begin{array}{l}\text { - Electricity, water, gas consumption via } \\
\text { meters/bills } \\
\text { - IEQ: building automation controls reading } \\
\text { of T and RH, student survey of indoor } \\
\text { sound insulation } \\
\text { - Occupant satisfaction survey about the } \\
\text { controllability of IAQ parameters and about } \\
\text { building controls ease of use } \\
\text { - Commissioning, maintenance program, use } \\
\text { of building automation control systems or } \\
\text { Building Energy Management Systems, and } \\
\text { end-user education efforts were evaluated } \\
\text { by documentation and survey of FM } \\
\text { personnel. }\end{array}$ & $\begin{array}{l}\text { - Concluded } 12 \text { POE } \\
\text { indicators with data } \\
\text { collection methods }\end{array}$ \\
\hline $\begin{array}{l}\text { Post-Occupancy } \\
\text { Evaluation for } \\
\text { Multi-Unit } \\
\text { Residential } \\
\text { Buildings }\end{array}$ & 2016 & $\begin{array}{l}\text { Open Green } \\
\text { Building Society }\end{array}$ & Canada & $\begin{array}{l}\text { Multi-unit } \\
\text { Residential } \\
\text { buildings }\end{array}$ & $\begin{array}{l}\text { - Required steps: Kick-off meeting and basic } \\
\text { information gathering, Building Manager } \\
\text { Survey, Occupant survey, Energy and water } \\
\text { use (ENERGY STAR }{ }^{\circledR} \text { Portfolio Manager is } \\
\text { recommended) } \\
\text { - Optional: Interviews with residents }\end{array}$ & $\begin{array}{l}\text { - Informative guide for } \\
\text { administrators, } \\
\text { without specifying } \\
\text { tools/devices }\end{array}$ \\
\hline
\end{tabular}


A landmark protocol is the PROBE (Post Occupancy Review of Building Engineering) study, in which three series of 23 case studies in total were evaluated using standardized methodology (evolving slightly from the first to the last case study), from 1995 to 2002 in the UK. The BUS (Building Use Studies) survey used in the PROBE studies has been used to evaluate over 700 buildings worldwide to date [113]. The BUS survey provides both a domestic (housing) version and a non-domestic version, and has become an integral part of many programs such as NABERS in Australia and Arup Appraise.

The Center for the Built Environment (CBE) at UC Berkeley is another pioneer in POE studies. The CBE occupant IEQ satisfaction survey is a web-based questionnaire and reporting tool developed in 2000 that has been implemented in over 1,200 buildings, with over 100,000 individual occupant responses (as of November 2017) [114]. Some protocols such as EcoSmart and ASHRAE's Performance Measurement Protocol (PMP) (described below) recommend using the CBE survey. CBE was also the first to use an IEQ mobile measurement cart (in the 1980s), which will be introduced with more details later. After the release of the PMP protocol, CBE adjusted their toolkit to better support the PMP protocol with both hardware and software [99].

Another well-developed protocol is NEAT (National Environmental Assessment Toolkit), developed in 2003 by a research team at Carnegie Mellon University in partnership with the U.S. General Services Administration for POE of 20 commercial office buildings. The core components of the NEAT toolkit include both hardware and software, including the IEQ cart, occupant survey, and Technical Attributes of Building Systems documenting. Later, NEAT was used for many other projects and in some cases included energy and thermal envelope evaluation. 
Another remarkable protocol is the PMP (Performance Measurement Protocols for Commercial Buildings), jointly developed by ASHRAE (American Society of Heating, Refrigerating, and Air-Conditioning Engineers), USGBC (The U.S. Green Building Council) and CIBSE (The Chartered Institution of Building Services Engineers, U.K.). PMP is the only protocol that classifies three levels of measurement and has the most published details: it specifies what should be measured, measurement methods and their cost, recommended indicators, industry standards, and benchmarks.

The protocols in Canada are correlated with each other. Keen Engineering (now Stantec) developed the EcoSmart protocol in 2005 and tested it in six Canadian buildings in 2006. Some of the researchers involved in the development of the EcoSmart protocol later created the International Initiative for a Sustainable Built Environment (iiSBE) protocol. The iiSBE project was funded by National Sciences and Engineering Research Council of Canada, iiSBE Canada, Stantec, and Ryerson University. Nine Canadian buildings were evaluated using the iiSBE protocol in 2014. The occupant survey used in the iiSBE project was based on the survey of NRCC in 2012. Recently, some researchers involved in the iiSBE project helped develop an open-source POE template for multi-unit residential buildings in British Columbia, Canada.

Table 3 indicates that the US, Canada and the UK are more advanced in terms of developing POE protocols. The current protocols are mostly aimed at residential buildings and office buildings. POE of medical buildings is more complicated. Rather than developing a protocol, the government of Alberta, Canada proposed a 10-step methodology to guide how to develop a BPE scorecard for healthcare facilities [115]. So far, academia has been the main practitioners of 
POE while the industry has shown increasing interests and efforts in either applying existing, or developing their own, POE protocols.

Most of the POE protocols summarized here include IEQ measurement, which generally includes numerous sensors and equipment. UC Berkeley created the first mobile instrumented cart in 1985 (described in [116]), which then evolved to a more sophisticated wireless cart, first used as a portable wireless monitoring system (PWMS) to support commissioning of underfloor air distribution systems [117] (Figure 10). The idea of an IEQ cart has been widely adopted later in many studies and protocols (Figure 11). In addition to saving measurement time, a major benefit of an IEQ cart is to enable consistent measurement of different levels of temperature. The mobile cart is usually placed in a location for several minutes as a snap-shot of IEQ. Longterm monitoring of IEQ requires sensors installed in the buildings (i.e., on the walls), which has historically been expensive. Thus, it only happens in special cases, and the monitoring sensors are usually limited to temperature, relative humidity and $\mathrm{CO}_{2}$.

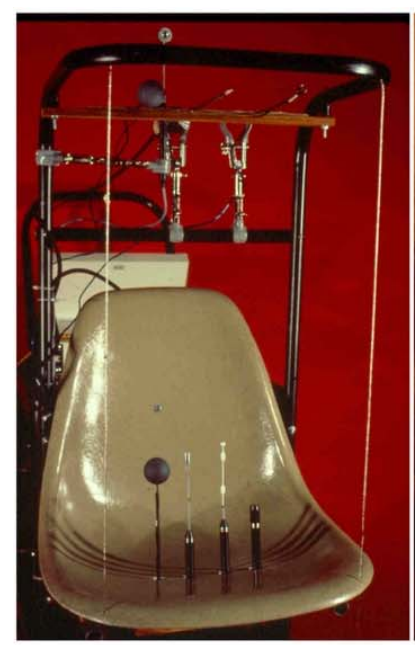

$1^{\text {st }}$ of it's kind (1985)

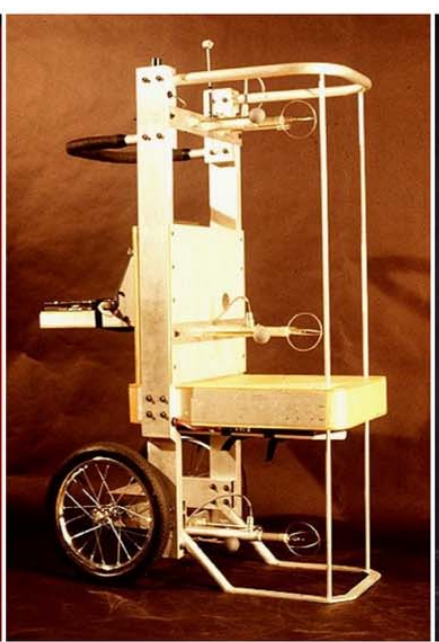

New \& improved (1990)

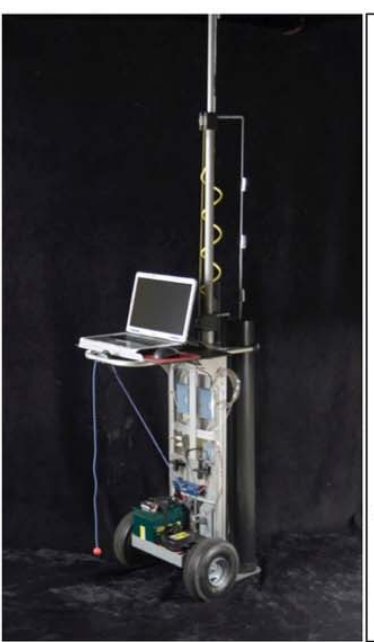

UFAD

Commissioning (2006)

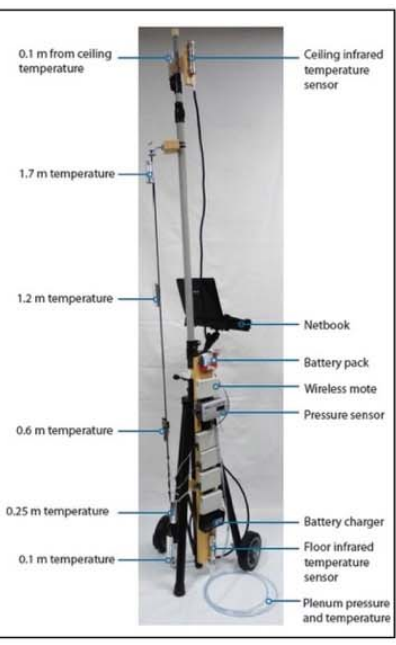

Wireless with real-time monitoring (2012) 


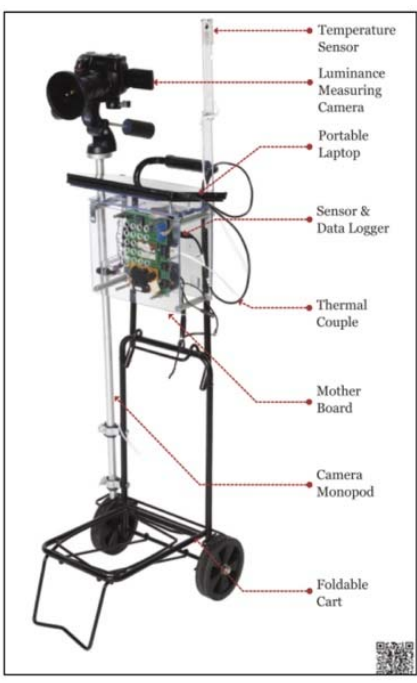

NEAT cart

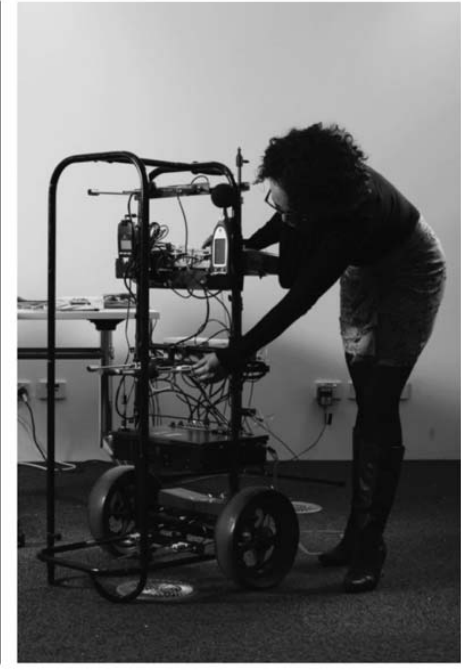

Nova in BOSSA

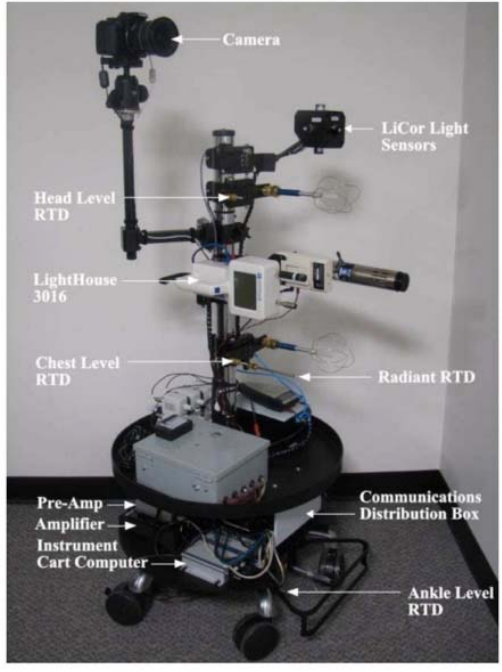

NICE in NRCC

Figure 11 Examples of other IEQ carts (Sources: [101,106,108])

Another critical component of a POE protocol is an occupant survey. BUS and CBE IEQ survey are the most widely used standardized surveys. They ask the respondents to rate various aspects of performance on a 7-point satisfaction scale to quantify occupant satisfaction. Their huge databases enable benchmarking, comparison and further analysis of buildings. Other standardized questionnaires include DQI (Design Quality Indicators), OLS (Overall Liking Score), REF (Ratings of Environmental Features), SCATs (Smart Controls and Thermal Comfort), COPE (Cost-effective Open-Plan Environments), HOPE (Health Optimization Protocol for Energyefficient Building), BASE (Building Assessment Survey and Evaluation), PWESQ (Physical Work Environment Questionnaire), NEP (New ecological paradigm), etc. Göçer et. al. [120] and Galatioto et. al. [121] provided reviews of the questionnaires above. Gupta and Chandiwala summarized short-term and long-term techniques to collect occupant feedback, with a focus on applications for housing [122]. 


\section{Emerging POE research topics}

In addition to evaluating the ways in which POE is used to evaluate a building's performance, this review also identified some broader, emerging research topics related to this field.

\subsection{Visualization of POE}

POE is a critical investigative methodology for understanding building performance. But it could be vastly more effective with improvements in how the results are analyzed, presented, and interpreted. POE results are often shown by charts in a report. To enhance the feedback to owner and occupants, BIM (Building Information Modelling) and GIS (Geographic Information Systems) are sometimes used to show the spatial mapping of occupant satisfaction and IEQ $[120,123]$. EnViz is a 3D-model-based software application that was developed to visualize IEQ data $[124,125]$. CBE at UC Berkeley also developed two interactive tools that allow users to explore the large sets of thermal comfort field data that combine both surveys and physical measurements [126].

\subsection{Analyses of Occupant Survey Databases}

In the last 5-10 years, researchers have been statistically analyzing POE databases to address novel questions about the performance of buildings from the perspective of human response, particularly in light of changes we are seeing in workplace design, such a greater attention to green building strategies, and the prevalence of open plan offices. Examples of these studies, using subsets of BUS, CBE or other occupant survey databases include: 
- Performance of green vs. conventional buildings [127-129];

- The advantages and disadvantages of a variety of forms of benchmarks for IEQ satisfaction [130];

- The effect of spatial configuration (open-plan office vs. enclosed office) on IEQ satisfaction [131];

- Gender differences in office occupant perception of IEQ [132,133];

- The relationships between occupant satisfaction and indoor environmental parameters and building feature [134];

- The relationships between individual IEQ factors and overall workspace satisfaction [135];

- Influence of non-IEQ factors (office type, spatial layout, distance from window, building size, gender, age, type of work, time at workspace, and weekly working hours) on occupant satisfaction [136].

\subsection{Measurement of Occupancy}

Measurement and verification of energy savings is an important component of green building certification as well as of energy retrofit projects. In many cases, however, the energy simulation during the design phase does not reflect the actual use patterns of the building, resulting in large gaps between the predicted and the actual energy use [110]. To solve this gap problem, the energy model should be revised to better match occupant density patterns. Yang et. al. considered the variability of daily occupancy and the additional occupancy due to visitors in institutional buildings to better predict the energy performance [137]. Using simplified baseline models to illustrate the effect, Liang et. al. incorporated an occupancy variable to a 
simple regression model developed by Lawrence Berkeley National Laboratory (LBNL) model that used just outdoor air temperature and time [138]. Niu et. al. developed a virtual reality (VR) integrated approach to help building designers collect occupancy information, and then used that to identify design strategies that could guide occupants to behave in the most energy-efficient way [139].This is a unique approach for integrating occupancy information more effectively into the building design process.

As we move towards evaluating actual performance, as opposed to predicted performance, it becomes increasingly important to use actual occupancy data. There have been ongoing conversations in the building industry about whether the conventional metric of Energy Use Intensity (EUI, kBtu/sq.ft) should be expressed in terms of energy used per person. Vale and Vale [140] took this idea even further, and said that future residential POE should connect the performance of the building with the inhabitants' lifestyle by linking the overall building/site consumption to the number of occupants, so that we could measure the resource use per person, waste production per person, transport, income, etc.

A simple way to calculate the actual occupancy is based on records of human resources, class enrolment numbers, class schedules, and recreational schedules [109], but this is not necessarily accurate. Techniques are available to measure the actual occupancy data [141], or proxies for occupancy (i.e., using questionnaire and interviews, radio frequency, infrared, ultrasound, video cameras, $\mathrm{CO}_{2}$, GPS (global positioning system), cellular data, WLAN (wireless local area network, Bluetooth, etc.). Researchers at University of Nottingham [142] tested three unobtrusive occupancy measuring technologies (i.e., Passive Infra-Red (PIR), Carbon Dioxide 
$\left(\mathrm{CO}_{2}\right)$, and Device-free Localization (DfL)), and found that windows and occupants' metabolic rates had significant impacts on the reliability of the PIR and $\mathrm{CO}_{2}$ data. DfL estimates the location and the activity of a person by analyzing its shadowing effect on surrounding wireless links. By applying a deep learning approach, Wang et. al proved that the DfL system could achieve $85 \%$ or higher accuracy based on experiments in laboratory and experiments in an apartment [143]. In addition, Sensible Building Science, a start-up company from the University of British Columbia, is engaged in one of the early efforts to leverage existing real-time Wi-Fi activity data to produce occupancy data for building automation system optimization [144]. Aftab et. al. [145] recently developed an occupancy-recognition algorithm to count the number of people crossing a virtual reference line (near the entrance) in the video captured by a fisheye camera. The real-time video processing can provide $80-90 \%$ accuracy of occupancy recognition.

\section{Discussion: Status and Future Research}

Although POE has not become a norm in the building industry, it has developed rapidly over the past decade and will continue growing as more people realize the importance of evaluating actual real-time performance and the important role of occupant feedback.

The methodology of POE has been sufficiently well developed that many POE protocols are in widespread use in the UK, the US, Canada, Australia and other countries. But no standardized POE protocol has gained worldwide or nation-wide dominance. It might be that the inherent nature of POE-i.e., that its purpose and associated methods are highly casedependent-makes it difficult to have a dominant standardized protocol for all the POE projects. Notwithstanding, one prevailing protocol for one type of buildings is highly possible, especially 
for residential buildings and office/commercial buildings where most of research efforts have been devoted.

From a closer perspective, it is inspiring that occupant feedback has become the major focus of POE studies, beyond the domain of social scientists. An occupant survey has become an essential piece of most POE methodologies, even by studies within the building sciences, which have traditionally focused on the physical performance of the building. This reflects that a wider range of researchers now acknowledge that it is the people who occupy the spaces that have the power to determine the success or failure of a building. However, researchers should be aware of the nuanced challenges to assessing users' experience of the built environment, including "defining users, agreeing on the meaning of experience, and organising if not delimiting what is included in the notion of built environment" [146].

Current POE studies also have limitations. Despite the large number of POE studies that have been conducted, because POE results are largely context-based, the knowledge gained can be difficult to generalize and then feed back to the whole building industry. Moreover, because of the frequent lack of integration between the design, construction and operation phases of a building, many POE projects are limited in terms of linking their evaluation back to the phases that were most responsible for the relative successes and failures. Pati and Pati [147] argue that designers have not fully benefitted from POEs. IPD (Integrated Project Delivery) might help avoid this, by bringing POE experts to the table where designers could pre-identify design decisions that need to be supported by POE. 
If we regard POE as a "technology" and refer to the technology adoption lifecycle proposed by Rogers [148] (Figure 12), where the adopters are categorized into innovators, early adopters, early majority, late majority, and laggards, we might argue that POE is just at the first stage-only innovators adopt POE. Some of the barriers to more widespread adoption of POE include the ambiguity of who pays for POE, defending professional territory, split incentives within the procurement and operation processes, lack of agreed-upon and reliable indicators, potential liability issues, exclusion from current delivery expectations, and exclusion from professional curricula, etc. $[149,150]$.

Moore [151] states that there is a chasm between the early adopters (Figure 12) where many technologies fail to be adopted by the mainstream. Rating systems for green building design (e.g., LEED, etc.) have already crossed the chasm-they are in the early majority stage. If we want POE to cross the chasm, we need to create a bandwagon effect in which enough momentum builds, and then POE becomes a de facto standard. The momentum can be internally driven (i.e., from building owners, operators, and occupants), or externally driven (i.e., from regulations, policies, LEED requirements, etc.).

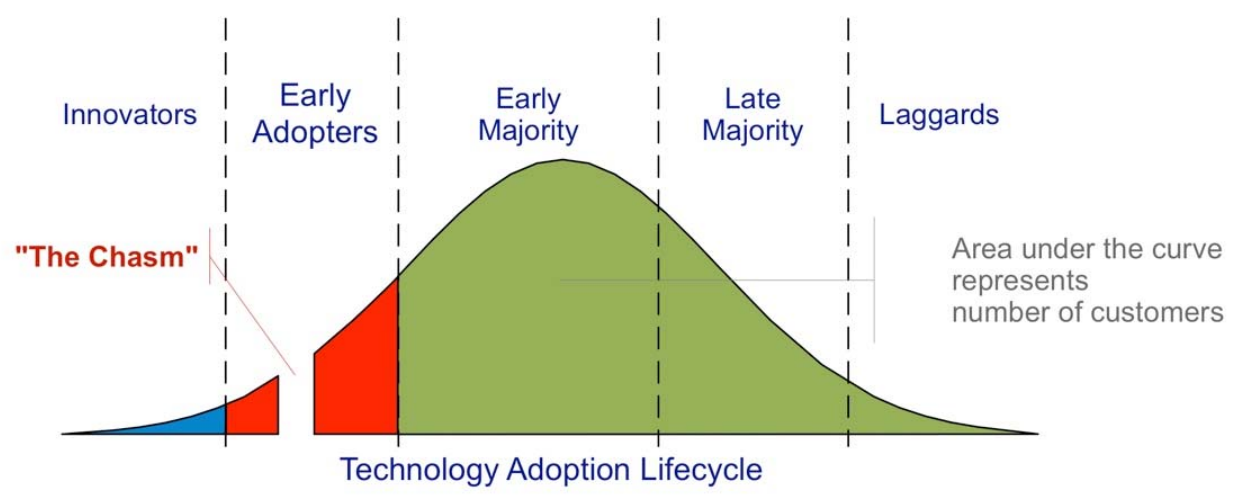

Figure 12 Technology Adoption Lifecycle (Source: Wikipedia Commons) 
In our opinion, POE can be more useful if the following transitions are made:

\section{From one-off to continuing}

Most of the POEs are one-off studies. However, in many cases, the studies found some problems that could not be fully explained, or on the contrary, no problems were identified. In some cases, this could be because the scope and methodology were not well defined. Thus, a more effective strategy would be to have a continuing POE with a phased approach to the level-of-detail in the methods; i.e., use relatively inexpensive and easy methods to evaluate broad aspects in the first phase, and then use those findings to decide which areas of the building or performance issues require further in-depth study in subsequent phases. Vischer [149] also mentioned the need for a few, carefully selected indicators of environmental quality and, considering the cost of instrument

measurements, she suggested to "use the analysis of user responses to indicate where and when follow-up instrument measures might clarify the nature of the problems identified and indicate possible solutions".

\section{From high-level to detailed}

Some high-level POE methods are standardized, while the more nuanced details of POE methods are less so, and may need to be standardized as well to render more reliable interpretation of the results. For example, high-level whole-building energy performance is easily measured via bills and meters. But we need more standardized methods to understand detailed end-use patterns, or to collect more accurate occupancy data to recalibrate the energy model and, thus, to enable a more fair and accurate comparison between the predicted and the actual performance. 


\section{From researchers-oriented to owners/occupants-oriented}

The POE results are often compiled in a report or a paper with all the technical figures and charts. However, non-professionals like the owners and occupants also need to understand the buildings' performance. Research is needed on how to provide more vivid visualization of POE results.

\section{From academia to industry}

Right now, academic researchers are the main developers and users of POE. Learning from the success of green building certifications worldwide, industry should play a stronger role in driving the development and implementation of POE.

\section{From independent to integrated}

POE is often a discrete activity, independent from the ongoing building management. But to exploit the effectiveness of the evaluation, it is better to regard POE as an integrated part of the building management. For example, one might continuously feed the results of occupant satisfaction surveys to the building automation control system, or feed the assessed facility conditions to the facility management system, etc. Although it was not a continuous process, an attempt was made by Cao et. al., who used a survey to quantify occupant satisfaction and then developed an agent-based model to prioritize maintenance work to achieve maximum occupant satisfaction [152].

\section{Conclusion}

The evaluation of building performance and occupant satisfaction in the post-occupancy phase is relatively under-developed compared to evaluation methods applied during a building's 
design phase. Yet POE has continued to attract increasing research attention over the past decade. The analysis of 146 POE projects since 2010 shows that residential buildings are the most popular research targets, occupant satisfaction is the most common focus, and occupant surveys are the most frequently used method. Many POE protocols have been proposed in the UK, the US, Canada, Australia and other countries, but no singular POE protocol has gained worldwide or nation-wide dominance. Some emerging research topics related to POE include visualization of POE results, analyses of occupant survey databases, and measurement of occupancy patterns.

Based on the literature review, we suggest five directions for future POE development and applications: from one-off to continuing, from high-level to detailed, from researchersoriented to owners/occupants-oriented, from academia to industry, and from independent to integrated. This paper provides a thorough introduction of POE to the beginners in this area, as well as informing more seasoned investigators about the trends, gaps, and potential future directions in POE research.

\section{Bibliography}

[1] U.S. Energy Information Administration, Buildings sector energy consumption, 2016. doi:www.eia.gov/forecasts/ieo/pdf/0484(2016).pdf.

[2] U.S. Energy Information Administration, Energy consumption by sector, (2017). https://www.eia.gov/totalenergy/data/monthly/\#consumption (accessed October 16, 2017).

[3] J.Zuo, Z.Y. Zhao, Green building research-current status and future agenda: A review, Renew. Sustain. Energy Rev. 30 (2014) 271-281. doi:10.1016/j.rser.2013.10.021.

[4] G. Herda, V. Autio, C. Lalande, Building Sustainability Assessment and Benchmarking - An Introduction, 2017. doi:10.1002/mrdd.20080.

[5] W. Wei, O. Ramalho, C. Mandin, Indoor air quality requirements in green building certifications, Build. Environ. 92 (2015) 10-19. doi:10.1016/j.buildenv.2015.03.035.

[6] International Living Future Institute, Living Building Challenge 3.0, 2014. http://livingfuture.org/sites/default/files/reports/FINAL LBC 3_0_WebOptimized_low.pdf.

[7] Delos Living LLC., The WELL Building Standard v1, 2015.

[8] BOMA, ABOUT BOMA BEST, (2017). http://bomacanada.ca/bomabest/aboutbomabest/ (accessed August 18, 
2017).

[9] AASHE, STARS Overview, (2017). https://stars.aashe.org/pages/about/stars-overview.html (accessed August 18, 2017).

[10] Office of Environment and Heritage on behalf of Federal State and Territory governments, National Australian Built Environment Rating System (NABERS), (2017). https://nabers.gov.au/public/webpages/home.aspx (accessed October 16, 2017).

[11] M.O. Sanni-Anibire, M.A. Hassanain, A.-M. Al-Hammad, Post-Occupancy Evaluation of Housing Facilities: Overview and Summary of Methods, J. Perform. Constr. Facil. 30 (2016). doi:10.1061/(ASCE)CF.19435509.0000868 .

[12] J.H.K. Lai, C.S. Man, J.H.K. Lai, C.S. Man, Developing a performance evaluation scheme for engineering facilities in commercial buildings: state-of-the-art review, 9179 (2017). doi:10.3846/1648715X.2016.1247304.

[13] A. Leaman, F. Stevenson, B. Bordass, Building evaluation: Practice and principles, Build. Res. Inf. 38 (2010) 564-577. doi:10.1080/09613218.2010.495217.

[14] K. Hadjri, C. Crozier, Post-occupancy evaluation: purpose, benefits and barriers, Facilities. 27 (2009) 21-33. doi:10.1108/02632770910923063.

[15] I. Cooper, Post-occupancy evaluation - Where are you?, Build. Res. Inf. 29 (2001) 158-163. doi:10.1080/09613210010016820.

[16] W.F.E. Preiser, Building Performance Assessment-From POE to BPE, A Personal Perspective, Archit. Sci. Rev. 48 (2005) 201-204. doi:10.3763/asre.2005.4826.

[17] W.F.E. Preiser, E. White, H. Rabinowitz, Post-Occupancy Evaluation, 1988.

[18] Federal Facilities Council, Learning from our buildings: A state-of-the-practice summary of Post-occupancy evaluation, 2002.

[19] J.E. Reckermann, CIRS pre-occupancy evaluation: inhabitant feedback processes and possibilities for a regenerative place, The University of British Columbia, 2014.

[20] S. Coleman, Normalizing Sustainability in a Regenerative Building: the Social Practice of Being at CIRS, The University of British Columbia, 2016.

[21] W.F.E. Preiser, Post-occupancy evaluation: how to make buildings work better, Facilities. 13 (1995) 19-28. doi:10.1108/02632779510097787.

[22] S. Kalantari, R. Snell, Post-Occupancy Evaluation of a Mental Healthcare Facility Based on Staff Perceptions of Design Innovations, HERD Heal. Environ. Res. Des. J. 10 (2017) 193758671668771. doi:10.1177/1937586716687714.

[23] L. Callaway, K. Tregloan, G. Williams, R. Clark, Evaluating Access and Mobility within a New Model of Supported Housing for People with Neurotrauma: A Pilot Study, Brain Impair. 17 (2016) 64-76. doi:10.1017/Brlmp.2016.7.

[24] N. Dikmen, S.T. Elias-Ozkan, Housing after disaster: A post occupancy evaluation of a reconstruction project, Int. J. Disaster Risk Reduct. 19 (2016) 167-178. doi:10.1016/j.ijdrr.2016.08.020.

[25] T. Wongbumru, B. Dewancker, Post-occupancy evaluation of user satisfaction: a case study of "old" and "new" public housing schemes in Bangkok, Archit. Eng. Des. Manag. 12 (2016) 107-124. doi:10.1080/17452007.2015.1106399.

[26] S. Grangaard, C. Ryhl, Vandhalla - A Sport Centre and a Successful Example of First-Generation Universal Design., Stud. Health Technol. Inform. 229 (2016) 243-245. http://search.ebscohost.com/login.aspx?direct=true\&db=mnh\&AN=27534310\&site=ehost-live\&scope=site.

[27] J. Dorsey, A. Hedge, Re-evaluation of a LEED Platinum Building: Occupant experiences of health and comfort, Work. 57 (2017) 31-41. doi:10.3233/WOR-172535.

[28] A.S. Ali, Shirley Jin Lin Chua, M.E.-L. Lim, The effect of physical environment comfort on employees' performance in office buildings: A case study of three public universities in Malaysia, Struct. Surv. 33 (2015) 294-308. doi:10.1108/09574090910954864.

[29] E. Mlecnik, T. Schütze, S.J.T. Jansen, G. De Vries, H.J. Visscher, A. Van Hal, End-user experiences in nearly zero-energy houses, Energy Build. 49 (2012) 471-478. doi:10.1016/j.enbuild.2012.02.045.

[30] T. Hwang, J.T. Kim, Effects of indoor lighting on occupants' visual comfort and eye health in a green building, Indoor Built Environ. 20 (2010) 75-90. doi:10.1177/1420326X10392017.

[31] A. Martinez-Molina, P. Boarin, I. Tort-Ausina, J.L. Vivancos, Post-occupancy evaluation of a historic primary 
school in Spain: Comparing PMV, TSV and PD for teachers' and pupils' thermal comfort, Build. Environ. 117 (2017) 248-259. doi:10.1016/j.buildenv.2017.03.010.

[32] S. Leder, G.R. Newsham, J. a. Veitch, S. Mancini, K.E. Charles, Effects of office environment on employee satisfaction: a new analysis, Build. Res. Inf. 3218 (2015) 1-17. doi:10.1080/09613218.2014.1003176.

[33] F. Martellotta, A. Simone, S. Della Crociata, M. D'Alba, Global comfort and indoor environment quality attributes for workers of a hypermarket in Southern Italy, Build. Environ. 95 (2016) 355-364. doi:10.1016/j.buildenv.2015.09.029.

[34] N. Khair, H.M. Ali, I. Sipan, N.H. Juhari, S.Z. Daud, Post occupancy evaluation of physical environment in public low-cost housing, J. Teknol. 75 (2015) 155-162. doi:10.11113/jt.v75.5284.

[35] M.F. Silva, S. Maas, H.A. de Souza, A.P. Gomes, Post-occupancy evaluation of residential buildings in Luxembourg with centralized and decentralized ventilation systems, focusing on indoor air quality (IAQ). Assessment by questionnaires and physical measurements, Energy Build. 148 (2017) 119-127. doi:10.1016/j.enbuild.2017.04.049.

[36] C. Brown, The power of qualitative data in post-occupancy evaluations of residential high-rise buildings, J. Hous. Built Environ. 31 (2016) 605-620. doi:10.1007/s10901-015-9481-2.

[37] M. Ferri, D.A. Zygun, A. Harrison, H.T. Stelfox, Evidence-based design in an intensive care unit: end-user perceptions., BMC Anesthesiol. 15 (2015) 57. doi:10.1186/s12871-015-0038-4.

[38] J. Mundo-Hernández, M.C. Valerdi-Nochebuena, J. Sosa-Oliver, Post-occupancy evaluation of a restored industrial building: A contemporary art and design gallery in Mexico, Front. Archit. Res. 4 (2015) 330-340. doi:10.1016/j.foar.2015.09.003.

[39] W.O. Collinge, A.E. Landis, A.K. Jones, L.A. Schaefer, M.M. Bilec, Productivity metrics in dynamic LCA for whole buildings: Using a post-occupancy evaluation of energy and indoor environmental quality tradeoffs, Build. Environ. 82 (2014) 339-348. doi:10.1016/j.buildenv.2014.08.032.

[40] M.M. Agha-Hossein, S. El-Jouzi, A.A. Elmualim, J. Ellis, M. Williams, Post-occupancy studies of an office environment: Energy performance and occupants' satisfaction, Build. Environ. 69 (2013) 121-130. doi:10.1016/j.buildenv.2013.08.003.

[41] M.-C. Zheng, M.-S. Chen, P.-Y. Li, Post-Occupancy Evaluation of Information Signs and Pre-Boarding Behavior in a Historic Railroad Station, J. Asian Archit. Build. Eng. 9 (2010) 177-184. doi:10.3130/jaabe.9.177.

[42] O. Guerra-Santin, N. Romero Herrera, E. Cuerda, D. Keyson, Mixed methods approach to determine occupants' behaviour - Analysis of two case studies, Energy Build. 130 (2016) 546-566. doi:10.1016/j.enbuild.2016.08.084.

[43] B. Sodagar, D. Starkey, The monitored performance of four social houses certified to the Code for Sustainable Homes Level 5, Energy Build. 110 (2016) 245-256. doi:10.1016/j.enbuild.2015.11.016.

[44] M.Y. Abbas, M. Othman, \& Puteri, Z. Megat, A. Rahman, Pre-school Classroom Environment: Significant upon Childrens' Play Behaviour?, Procedia -Social Behav. Sci. 49 (2012) 47-65. doi:10.1016/j.sbspro.2012.07.005.

[45] C. Brown, M. Gorgolewski, Understanding the role of inhabitants in innovative mechanical ventilation strategies, Build. Res. Inf. 0 (2014) 1-13. doi:10.1080/09613218.2015.963350.

[46] R. Bozovic-Stamenovic, N. Kishnani, B.K. Tan, D. Prasad, F. Faizal, Assessment of awareness of Green Mark (GM) rating tool by occupants of GM buildings and general public, Energy Build. 115 (2016) 55-62. doi:10.1016/j.enbuild.2015.01.003.

[47] X. Xuan, Effectiveness of indoor environment quality in LEED-certified healthcare settings, Indoor Built Environ. 0 (2015) 1-13. doi:10.1177/1420326X15587564.

[48] K.J. Watson, J. Evans, A. Karvonen, T. Whitley, Capturing the social value of buildings: The promise of Social Return on Investment (SROI), Build. Environ. 103 (2016) 289-301. doi:10.1016/j.buildenv.2016.04.007.

[49] C. Filippín, S.F. Larsen, L. Marek, Experimental monitoring and post-occupancy evaluation of a non-domestic solar building in the central region of Argentina, Energy Build. 92 (2015) 267-281. doi:10.1016/j.enbuild.2015.01.053.

[50] R. Gupta, L. Barnfield, T. Hipwood, Impacts of community-led energy retrofitting of owner-occupied dwellings, Build. Res. Inf. 42 (2014) 446-461. doi:10.1080/09613218.2014.894742.

[51] W. Glad, Housing renovation and energy systems: the need for social learning, Build. Res. Inf. 40 (2012) 274289. doi:10.1080/09613218.2012.690955.

[52] M.S. Rashwan, M. Duhoux, Benchmarking energy performance for LEED residential homes in Manitoba, 2015 IEEE Electr. Power Energy Conf. Smarter Resilient Power Syst. EPEC 2015. (2016) 87-92. 
doi:10.1109/EPEC.2015.7379932.

[53] R. V. Jones, S. Goodhew, P. De Wilde, Measured indoor temperatures, thermal comfort and overheating risk: Post-occupancy evaluation of low energy houses in the UK, Energy Procedia. 88 (2016) 714-720. doi:10.1016/j.egypro.2016.06.049.

[54] M. Lakeridou, M. Ucci, A. Marmot, I. Ridley, The potential of increasing cooling set-points in air-conditioned offices in the UK, Appl. Energy. 94 (2012) 338-348. doi:10.1016/j.apenergy.2012.01.064.

[55] N. Mathiasen, A.K. Frandsen, How to frame universal workspace lighting, Stud. Health Technol. Inform. 229 (2016) 379-381. doi:10.3233/978-1-61499-684-2-379.

[56] H. Alzoubi, S. Al-Rqaibat, R.F. Bataineh, Pre-versus post-occupancy evaluation of daylight quality in hospitals, Build. Environ. 45 (2010) 2652-2665. doi:10.1016/j.buildenv.2010.05.027.

[57] Z. Wang, H. Zhao, B. Lin, Y. Zhu, Q. Ouyang, J. Yu, Investigation of indoor environment quality of Chinese large-hub airport terminal buildings through longitudinal field measurement and subjective survey, Build. Environ. 94 (2015) 593-605. doi:10.1016/j.buildenv.2015.10.014.

[58] J.N. Hill, S.L. LaVela, Noise levels in patient rooms and at nursing stations at three VA medical centers, Heal. Environ. Res. Des. J. 9 (2015) 54-63. doi:10.1177/1937586715592635.

[59] Y. Ning, J. Chen, Improving residential satisfaction of university dormitories through post-occupancy evaluation in China: A socio-technical system approach, Sustain. 8 (2016). doi:10.3390/su8101050.

[60] M.O. Sanni-Anibire, M.A. Hassanain, Quality assessment of student housing facilities through postoccupancy evaluation, Archit. Eng. Des. Manag. 12 (2016) 367-380. doi:10.1080/17452007.2016.1176553.

[61] S. Yildiz, C. Polatoglu, Evaluating the Built Environment in the Context of Barrier Free Tourism, a Case Study in Istanbul, 2nd Int. Sci. Conf. Tour. South. East. Eur. 2013 Cris. - a Chall. Sustain. Tour. Dev. 2 (2013) 435446.

[62] M.M. Shepley, Z. Rybkowski, J. Aliber, C. Lange, Ambulatory infusion suite: pre- and post-occupancy evaluation, Build. Res. Inf. 40 (2012) 700-712. doi:10.1080/09613218.2012.709372.

[63] H.N. Husin, A.H. Nawawi, F. Ismail, N. Khalil, Correlation Analysis of Occupants' Satisfaction and Safety Performance Level in Low Cost Housing, Procedia - Soc. Behav. Sci. 168 (2015) 238-248. doi:10.1016/j.sbspro.2014.10.229.

[64] N. Bento Pereira, R. Calejo Rodrigues, P. Fernandes Rocha, Post-Occupancy Evaluation Data Support for Planning and Management of Building Maintenance Plans, Buildings. $6 \quad$ (2016) 45. doi:10.3390/buildings6040045.

[65] S.H. Kwon, C. Chun, R.Y. Kwak, Relationship between quality of building maintenance management services for indoor environmental quality and occupant satisfaction, Build. Environ. 46 (2011) 2179-2185. doi:10.1016/j.buildenv.2011.04.028.

[66] K. Strelets, E. Perlova, M. Platonova, A. Pankova, M. Romero, M.S. Al-Shabab, Post Occupancy Evaluation (POE) and Energy Conservation Opportunities (ECOs) Study for Three Facilities in SPbPU in Saint Petersburg, Procedia Eng. 165 (2016) 1568-1578. doi:10.1016/j.proeng.2016.11.895.

[67] A.O. Abisuga, I.O. Famakin, O.S. Oshodi, Educational building conditions and the health of users, Constr. Econ. Build. 16 (2016) 19-34. doi:: http://dx.doi.org/10.5130/AJCEB.v\%25vi\%25i.4979.

[68] R.S. McLeod, M. Swainson, Chronic overheating in low carbon urban developments in a temperate climate, Renew. Sustain. Energy Rev. 74 (2017) 201-220. doi:10.1016/j.rser.2016.09.106.

[69] R. Gupta, M. Kapsali, Empirical assessment of indoor air quality and overheating in low-carbon social housing dwellings in England, UK, Adv. Build. Energy Res. 2549 (2015) 1-23. doi:10.1080/17512549.2015.1014843.

[70] T.O. Adekunle, M. Nikolopoulou, Thermal comfort, summertime temperatures and overheating in prefabricated timber housing, Build. Environ. 103 (2016) 21-35. doi:10.1016/j.buildenv.2016.04.001.

[71] J. Day, J. Theodorson, K. Van Den Wymelenberg, Understanding controls, behaviors and satisfaction in the daylit perimeter office: A daylight design case study, J. Inter. Des. 37 (2012) 17-34. doi:10.1111/j.19391668.2011.01068.x.

[72] L.E. Thomas, Evaluating design strategies, performance and occupant satisfaction: a low carbon office refurbishment, Build. Res. Inf. 38 (2010) 610-624. doi:10.1080/09613218.2010.501654.

[73] C.P. DeClercq, G. Cranz, Moving Beyond Seating-centered Learning Environments: Opportunities and Challenges Identified in a POE of a Campus Library, J. Acad. Librariansh. 40 (2014) 574-584. doi:10.1016/j.acalib.2014.08.005.

[74] L. Guinther, A. Carll-White, K. Real, One Size Does Not Fit All: A Diagnostic Post-Occupancy Evaluation Model 
for an Emergency Department, HERD Heal. Environ. Res. Des. J. 7 (2014) 15-37. doi:10.1177/193758671400700303.

[75] C. Spataru, M. Gillott, The Use of Intelligent Systems for Monitoring Energy Use and Occupancy in Existing Homes, Smart Innov. Syst. Technol. 7 (2011) 247-256. doi:10.1007/978-3-642-17387-5_25.

[76] J.Zuo, X.L. Yuan, S. Pullen, Post Occupancy Evaluation Study in Hospital Buildings - a Pilot Study, Appl. Mech. Mater. 94-96 (2011) 2248-2256. doi:10.4028/www.scientific.net/AMM.94-96.2248.

[77] D.A. Guerin, J.K. Brigham, H.-Y. Kim, S. Choi, A. Scott, Post-Occupancy Evaluation of Employees' Work Performance and Satisfaction As Related To Sustainable Design Criteria and Workstation Type, J. Green Build. 7 (2012) 85-99. doi:10.3992/jgb.7.4.85.

[78] R.A. Mangkuto, K.A. Kurnia, D.N. Azizah, R.T. Atmodipoero, F.X.N. Soelami, Determination of discomfort glare criteria for daylit space in Indonesia, Sol. Energy. 149 (2017) 151-163. doi:10.1016/j.solener.2017.04.010.

[79] P. Xue, C.M. Mak, Y. Huang, Quantification of luminous comfort with dynamic daylight metrics in residential buildings, Energy Build. 117 (2016) 99-108. doi:10.1016/j.enbuild.2016.02.026.

[80] M.B. Hirning, G.L. Isoardi, S. Coyne, V.R. Garcia Hansen, I. Cowling, Post occupancy evaluations relating to discomfort glare: A study of green buildings in Brisbane, Build. Environ. 59 (2013) 349-357. doi:10.1016/j.buildenv.2012.08.032.

[81] J.H. Choi, V. Loftness, A. Aziz, Post-occupancy evaluation of 20 office buildings as basis for future IEQ standards and guidelines, Energy Build. 46 (2012) 167-175. doi:10.1016/j.enbuild.2011.08.009.

[82] R. Smutny, M. Treberspurg, Sustainability Monitoring of Viennese Housing Estates. Post-OccupancyEvaluation, Energy Monitoring and Cost Analysis of Passive and Low Energy Housing Estates, Cesb 10 Cent. Eur. Towar. Sustain. Build. - From Theory To Pract. (2010) 341-344.

[83] T. Williamson, V. Soebarto, A. Radford, Comfort and energy use in five Australian award-winning houses: regulated, measured and perceived, Build. Res. Inf. 38 (2010) 509-529. doi:10.1080/09613218.2010.494890.

[84] L. Thomas, Combating overheating: mixed-mode conditioning for workplace comfort, Build. Res. Inf. 45 (2017) 176-194. doi:10.1080/09613218.2017.1252617.

[85] R. Schiano-Phan, Post-occupancy evaluation of non-domestic buildings using passive downdraught evaporative cooling in south-west USA, Archit. Sci. Rev. 55 (2012) 320-340. doi:10.1080/00038628.2012.725535.

[86] M. Berge, H.M. Mathisen, Perceived and measured indoor climate conditions in high-performance residential buildings, Energy Build. 127 (2016) 1057-1073. doi:10.1016/j.enbuild.2016.06.061.

[87] J. Damiens, M. Li, Z. Pei, Y. Liu, Y. Zhu, Using Natural Ventilation in Office Buildings Under Subtropical Climate: A case Study in Shenzhen, in: Proc. 8th Int. Symp. Heating, Vent. Air Cond., Springer, Berlin, Heidelberg, 2014: pp. 381-388. doi:10.1007/978-3-642-39581-9.

[88] L.P. and K.T. Mark Perepelitza, Performance validation case study: Federal office building with an integrated facade, J. Build. Phys. Vol. 39(6) (2016) 542-569. doi:10.1177/1744259115611871.

[89] X. Deng, G. Kokogiannakis, Z. Ma, P. Cooper, Thermal Comfort Evaluation of a Mixed-mode Ventilated Office Building with Advanced Natural Ventilation and Underfloor air Distribution Systems, Energy Procedia. 111 (2017) 520-529. doi:10.1016/j.egypro.2017.03.214.

[90] M.B. Hirning, G.L. Isoardi, V.R. Garcia-Hansen, Prediction of discomfort glare from windows under tropical skies, Build. Environ. 113 (2017) 107-120. doi:10.1016/j.buildenv.2016.08.005.

[91] A.C. Menezes, A. Cripps, D. Bouchlaghem, R. Buswell, Predicted vs. actual energy performance of nondomestic buildings: Using post-occupancy evaluation data to reduce the performance gap, Appl. Energy. 97 (2012) 355-364. doi:10.1016/j.apenergy.2011.11.075.

[92] A.M. Radwan, M.H. Issa, An Evaluation of Indoor Environmental Quality and Occupant Well-Being in Three Southern Rural Manitoba School Buildings, J. Green Build. (2014) 123-141.

[93] T. Hwang, J.T. Kim, Assessment of Indoor Environmental Quality in Open-Plan Offices, Indoor Built Environ. . 22 (2013) 139-156. doi:10.1177/1420326X12470280.

[94] J.H. Choi, J. Moon, Impacts of human and spatial factors on user satisfaction in office environments, Build. Environ. 114 (2017) 23-35. doi:10.1016/j.buildenv.2016.12.003.

[95] C. Alvaro, A.J. Wilkinson, S.N. Gallant, D. Kostovski, P. Gardner, Evaluating Intention and Effect: The Impact of Healthcare Facility Design on Patient and Staff Well-Being, Heal. Environ. Res. Des. J. 9 (2016) 82-104. doi:10.1177/1937586715605779. 
[96] CIBSE, PROBE - Post Occupancy Studies, (n.d.). http://www.cibse.org/building-services/building-servicescase-studies/probe-post-occupancy-studies (accessed August 10, 2017).

[97] CIBSE, Probe 2 Research methods, CIBSE J. (1997) 1-5.

[98] L. Zagreus, C. Huizenga, E. Arens, D. Lehrer, Listening to the occupants: a Web-based indoor environmental quality survey., Indoor Air. 14 (2004) 65-74. doi:10.1111/j.1600-0668.2004.00301.x.

[99] D. Heinzerling, Tom Webster, S. Schiavon, G. Anwar, D. Dickerhoff, A prototype toolkit for evaluating indoor environmental quality in commercial buildings, Intern. Report, Cent. Built Environ. UC Berkeley. (2013) 8. https://escholarship.org/uc/item/7jh9h72t.

[100] J. PARK, A. AZIZ, K. LI, C. COVINGTON, Energy performance modeling of an office building and its evaluation, in: 18th Int. Conf. Comput. Archit. Des. Res. Asia (CAADRIA 2013), Singpore, 2013: pp. 209-218.

[101] Center for Building Performance and Diagnostics, National Environmental Assessment Toolkit Poster, n.d.

[102] K.M. Fowler, K.L. Spees, A.R. Kora, E.M. Rauch, J.E. Hathaway, A.E. Solana, Whole Building Cost and Performance Measurement: Data Collection Protocol Revision 2, 2009. doi:10.2172/990595.

[103] Keen Engineering, POST OCCUPANCY EVALUATION PROJECT REPORT COMPLETION OF PHASE 1: POE PROTOCOL DEVELOPMENT, 2006.

[104] ASHRAE, Performance measurement protocols for commercial buildings, 2010.

[105] M. Gillott, L. Taranto, C. Spataru, Low-carbon housing design informed by research, Proc. ICE-Engineering Sustain. 163 (2010) 77-87. doi:10.1680/ensu.2010.163.

[106] C. Candido, J. Kim, R. de Dear, L. Thomas, BOSSA: a multidimensional post-occupancy evaluation tool, Build. Res. Inf. 3218 (2015) 1-16. doi:10.1080/09613218.2015.1072298.

[107] G. Newsham, B. Birt, C. Arsenault, Do green buildings outperform conventional buildings? Indoor environment and energy performance in North American offices, 2012. doi:http://dx.doi.org/10.4224/20857897.

[108] G. Newsham, B.J. Birt, C. Arsenault, A.J.L. Thompson, J. a. Veitch, S. Mancini, A.D. Galasiu, B.N. Gover, I. a. Macdonald, G.J. Burns, Do "green" buildings have better indoor environments? New evidence, Build. Res. Inf. 41 (2013) 415-434. doi:10.1080/09613218.2013.789951.

[109] M. Gorgolewski, C. Brown, A. Chu, A. Turcato, K. Bartlett, G. Ebrahimi, M. Hodgson, S. Mallory-hill, M. Ouf, L. Scannell, Performance of Sustainable Buildings in Colder Climates, J. Green Build. 11 (2016) 131-153. doi:10.3992/jgb.11.4.131.1.

[110] A. Bartlett, Karen; Brown, Craig; Chu, Anne-Mareike; Ebrahimi, Ghazal; Gorgolewski, Mark; Hodgson, Murray; Issa, Mohamed; Mallory-Hill, Shauna; Ouf, Mohamed; Scannell, Leila; Turcato, Do our green buildings perform as intended?, in: World Sustain. Build. Conf., 2014.

[111] N. Alborz, U. Berardi, A post occupancy evaluation framework for LEED certified U.S. higher education residence halls, Procedia Eng. 118 (2015) 19-27. doi:10.1016/j.proeng.2015.08.399.

[112] Open Green Building Society, POST-OCCUPANCY EVALUATION FOR MULTI-UNIT RESIDENTIAL BUILDINGS, 2016.

[113] Arup, BUS methodology, (2017). http://www.busmethodology.org.uk (accessed August 24, 2017).

[114] CBE, Occupant Indoor Environmental Quality (IEQ) Survey and Building Benchmarking, (2017). http://www.cbe.berkeley.edu/research/briefs-survey.htm.

[115] C. Steinke, L. Webster, M. Fontaine, Evaluating building performance in healthcare facilities: An organizational perspective, Heal. Environ. Res. Des. J. 3 (2010) 63-83. doi:10.1177/193758671000300207.

[116] G. Schiller, E. Arens, F. Bauman, C. Benton, M. Fountain, T. Doherty, K. Craik, A field study of thermal environments and comfort in office buildings, ASHRAE Trans. 94 (1988).

[117] F. Bauman, T. Webster, S. Schiavon, H. Zhang, E. Arens, Advanced Design and Commissioning Tools for Energy-Efficient Building Technologies, 2012.

[118] C. Benton, F. Bauman, M. Fountain, A Field Measurement System for the Study of Thermal Comfort, ASHRAE Trans. 96 (1990) 623-633.

[119] T. Webster, F. Bauman, G. Anwar, CBE Portable Wireless Monitoring System (PWMS): UFAD Systems Commissioning Cart Design Specifications and Operating Manual, Intern. Report, Cent. Built Environ. UC Berkeley. (2007) 4. https://escholarship.org/uc/item/8v1347vp.

[120] Ö. Göçer, Y. Hua, K. Göçer, Completing the missing link in building design process: Enhancing post-occupancy evaluation method for effective feedback for building performance, Build. Environ. 89 (2015) 14-27. doi:10.1016/j.buildenv.2015.02.011. 
[121] A. Galatioto, G. Leone, D. Milone, S. Pitruzzella, V. Franzitta, Indoor Environmental Quality Survey: A Brief Comparison between Different Post Occupancy Evaluation Methods, Adv. Mater. Res. 864-867 (2013) 11481152. doi:10.4028/www.scientific.net/AMR.864-867.1148.

[122] R. Gupta, S. Chandiwala, Understanding occupants: feedback techniques for large-scale low-carbon domestic refurbishments, Build. Res. Inf. 38 (2010) 530-548. doi:10.1080/09613218.2010.495216.

[123] Y. Hua, Ö. Göçer, K. Göçer, Spatial mapping of occupant satisfaction and indoor environment quality in a LEED platinum campus building, Build. Environ. 79 (2014) 124-137. doi:10.1016/j.buildenv.2014.04.029.

[124] P. Patlakas, H. Santacruz, H. Altan, Development and Evaluation of a Prototype Software Application for the $\begin{array}{llllll}\text { Visualization of } & \text { Environmental } & 137-146 .\end{array}$ http://cumincad.architexturez.net/system/files/pdf/ecaade2013_029.content.pdf.

[125] P. Patlakas, H. Becerra-Santacruz, H. Altan, Visualising the environmental conditions of buildings, Proc. Inst. Civ. Eng. 167 (2014) 9. doi:http://dx.doi.org/10.1680/cien.13.00014.

[126] M. Pigman, H. Zhang, A. Honnekeri, E. Arens, G. Brager, Visualizing the results of thermal comfort field studies: putting publicly accessible data in the hands of practitioners, in: Proc. 8th Wind. Conf. Count. Cost Comf. a Chang. World, Windsor, UK, 2014. doi:10.1080/09613218.2011.556008.

[127] S. Altomonte, S. Schiavon, Occupant satisfaction in LEED and non-LEED certified buildings, Build. Environ. 68 (2013) 66-76. doi:10.1016/j.buildenv.2013.06.008.

[128] G. Baird, A. Leaman, J. Thompson, A comparison of the performance of sustainable buildings with conventional buildings from the point of view of the users, Archit. Sci. Rev. 55 (2012) 135-144. doi:10.1080/00038628.2012.670699.

[129] S. Abbaszadeh, L. Zagreus, D. Lehrer, C. Huizenga, Occupant Satisfaction with Indoor Environmental Quality in Green Buildings, in: Heal. Build., 2006: pp. 365-370. http://escholarship.org/uc/item/9rf7p4bs.

[130] C. Dykes, G. Baird, Performance benchmarks for non-domestic buildings: towards user perception benchmarks, Build. Res. Inf. 42 (2014) 62-71. doi:10.1080/09613218.2014.832103.

[131] J. Kim, R. de Dear, Workspace satisfaction: The privacy-communication trade-off inopen-plan offices, J. Environ. Psychol. 36 (2013) 18-26. doi:10.1016/j.jenvp.2013.06.007.

[132] J. Kim, R. de Dear, C. Candido, H. Zhang, E. Arens, Gender differences in office occupant perception of indoor environmental quality (IEQ), Build. Environ. 70 (2013) 245-256. doi:10.1016/j.buildenv.2013.08.022.

[133] J. Choi, A. Aziz, V. Loftness, Investigation on the impacts of different genders and ages on satisfaction with thermal environments in office buildings, Build. Environ. 45 (2010) 1529-1535. doi:10.1016/j.buildenv.2010.01.004.

[134] M. Frontczak, S. Schiavon, J. Goins, E. Arens, H. Zhang, P. Wargocki, Quantitative relationships between occupant satisfaction and satisfaction aspects of indoor environmental quality and building design, Indoor Air. 22 (2012) 119-131. doi:10.1111/j.1600-0668.2011.00745.x.

[135] J. Kim, R. de Dear, Nonlinear relationships between individual IEQ factors and overall workspace satisfaction, Build. Environ. 49 (2012) 33-40. doi:10.1016/j.buildenv.2011.09.022.

[136] S. Schiavon, S. Altomonte, Influence of factors unrelated to environmental quality on occupant satisfaction in LEED and non-LEED certified buildings, Build. Environ. $77 \quad$ (2014) $148-159$. doi:10.1016/j.buildenv.2014.03.028.

[137] J. Yang, M. Santamouris, S.E. Lee, C. Deb, Energy performance model development and occupancy number identification of institutional buildings, Energy Build. $123 \quad$ (2016) $192-204$. doi:10.1016/j.enbuild.2015.12.018.

[138] X. Liang, T. Hong, G.Q. Shen, Improving the accuracy of energy baseline models for commercial buildings with occupancy data, Appl. Energy. 179 (2016) 247-260. doi:10.1016/j.apenergy.2016.06.141.

[139] S. Niu, W. Pan, Y. Zhao, A virtual reality integrated design approach to improving occupancy information integrity for closing the building energy performance gap, Sustain. Cities Soc. 27 (2016) 275-286. doi:10.1016/j.scs.2016.03.010.

[140] B. Vale, R. Vale, Domestic energy use, lifestyles and POE: past lessons for current problems, Build. Res. Inf. 38 (2010) 578-588. doi:10.1080/09613218.2010.481438.

[141] J. Yang, M. Santamouris, S.E. Lee, Review of occupancy sensing systems and occupancy modeling methodologies for the application in institutional buildings, Energy Build. 121 (2016) 344-349. doi:10.1016/j.enbuild.2015.12.019.

[142] E. Naghiyev, M. Gillott, R. Wilson, Three unobtrusive domestic occupancy measurement technologies under 
qualitative review, Energy Build. 69 (2014) 507-514. doi:10.1016/j.enbuild.2013.11.033.

[143] J. Wang, X. Zhang, Q. Gao, H. Yue, H. Wang, Device-free wireless localization and activity recognition with deep learning, IEEE Trans. Veh. Technol. 66 (2017) 6258-6267. doi:10.1109/PERCOMW.2016.7457118.

[144] Sensible Building Science, Solutions, (2017). http://sensiblebuildingscience.com/solutions/ (accessed September 6, 2017).

[145] M. Aftab, C. Chen, C. Chau, T. Rahwan, Automatic HVAC Control with Real-time Occupancy Recognition and Simulation-guided Model Predictive Control in Low-cost Embedded System, Energy Build. 154 (2017) 141156. doi:10.1016/j.enbuild.2017.07.077.

[146] J.C. Vischer, Towards a user-centred theory of the built environment, Build. Res. Inf. 36 (2008) $231-240$. doi:10.1080/09613210801936472.

[147] D. Pati, S. Pati, Methodological issues in conducting post-occupancy evaluations to support design decisions, Heal. Environ. Res. Des. J. 6 (2013) 157-163. doi:10.1177/193758671300600312.

[148] E.M. Rogers, Diffusion of Innovations, 1st ed., New York: Free Press of Glencoe, 1962.

[149] J.C. Vischer, Post-Occupancy Evaluation: A Multifaceted Tool for Building Improvement, in: Learn. From Our Build. A State-of-the-Practice Summ. Post-Occupancy Eval., 2001: p. 23.

[150] A. Zimmerman, M. Martin, Post-occupancy evaluation: Benefits and barriers, Build. Res. Inf. 29 (2001) 168174. doi:10.1080/09613210010016857.

[151] G.A. Moore, Crossing the Chasm: Marketing and Selling High-Tech Products to Mainstream Customers, 1st ed., 1991.

[152] Y. Cao, T. Wang, X. Song, An energy-aware, agent-based maintenance-scheduling framework to improve occupant satisfaction, Autom. Constr. 60 (2015) 49-57. doi:10.1016/j.autcon.2015.09.002. 